\title{
Corporate Governance, Board Composition, Director Expertise, and Value: The Case of Quality Excellence
}

\author{
Andreas Charitou \\ University of Cyprus, Cyprus \\ Ifigenia Georgiou \\ Aston Business School, UK and \\ Cyprus International Institute of Management, Cyprus \\ Andreas Soteriou \\ University of Cyprus, Cyprus
}

In this paper, we highlight the strategic role of the board of directors (BOD) in business excellence and its link with firm value. We empirically investigate the relationship between the composition of the BOD and the winning of a Malcolm Baldrige National Quality Award (MBNQA) or a local award explicitly based on the MBNQA criteria, a proxy for business excellence. Using a contingency approach, we examine several characteristics of the BOD, such as the number of inside directors, the number of directors who can be considered industry experts, and the number of directors with management expertise. We show that the likelihood of winning a quality award is positively associated with the number of outside directors with Ph.D. in the main object of business operations, and the number of outside directors with recent industry expertise. Subsequent residual analysis reveals that firm value is positively associated with the degree of the fit between board composition and quality management strategy. Specifically, operating income before depreciation, operating margin, Tobin's Q, and ten-day raw and market adjusted returns, are positively related to the degree of fit, while cost per dollar of sales, negatively. Thus, we, conclude that an appropriate board structure that fits the QM strategy exists, and this fit is positively associated with firm value. (JEL: G30, G34, M10)

Keywords: board of directors; corporate governance; director expertise;

strategic role of the board; quality management; quality awards

* The authors would like to thank Dr. Anastasia Kopita for her valuable input.

(Multinational Finance Journal, 2016, vol. 20, no. 3, pp. 181-236)

(C) Multinational Finance Society, a nonprofit corporation. All rights reserved. DOI: $10.17578 / 20-3-1$ 
Article history: Received: 6 November 2013, Received in final revised form: 26 April 2016, Accepted: 26 July 2016, Available online: 22 February 2017

\section{Introduction}

The corporate governance conditions that foster business performance excellence, and thus, enhance shareholder value creation are largely unknown to us, as the literature has been dominated by studies that focus on organizational distress cases or crises, and thus focus on the monitoring role of the board and the ability of the directors to prevent value loss, rather than their ability to add value (Daily, Dalton, and Cannella, 2003; Faleye, 2014). The purpose of this study is to investigate the relationship between corporate governance, performance excellence, and shareholder value creation. To this end we employ a quality management (QM) setting, and specifically, the winning of the prestigious Malcolm Baldrige National Quality Award (MBNQA) as a platform from which to shed light on the corporate governance of firms that take the leap to go beyond survival and pursue excellence, and to investigate how this is linked to shareholder value.

The MBNQA is by itself, a "culture of performance excellence" (Paul Borawski, CEO of the American Society for Quality, as cited by Jacob, Madu, and Tang, 2012, p. 234). The verdict on winning the MBNQA is that it generates significant shareholder value for winners and is viewed favorably by investors (Balasubramanian, Mathur, Thakur, 2005; Jacob et al., 2012). A series of studies have shown how quality award winning and quality certification announcements create positive abnormal returns for firms (see Hendricks and Singhal, 1996; Nicolau and Sellers, 2002; Corbett Montes-Sancho, and Kirsch, 2005). Moreover, financial performance improvements can be observed as soon as an effective QM program is in place (Hendricks and Singhal, 2001a; Przasnyski and Tai, 2002). This relationship appears to persist in the long run, both for performance measured by accounting variables as well as stock returns (Hendricks and Singhal, 2001a; Easton and Jarrell, 1998; Corbett et al., 2005).

Given the well-established, positive and persistent relationship between quality and firm performance, it is important to extend our understanding of organizational attributes and structures that are related to this achievement. Furthermore, it is important to explore how these characteristics are related to firm value. Quality excellence is more often than not, the result of conscious efforts; it is the result of effective QM. A critical factor for achieving quality excellence is the existence 
of a sound QM strategy (Sandholm, 2005; Soltani, Lai, Javadeen, and Gholipour, 2008). Given the documented, prominent role of the board of directors in strategy, it is surprising that, to the best of our knowledge, the relationship between the firm's corporate governance, the success of QM strategy, and firm value has not yet been explored. ${ }^{1}$ In this study, we empirically investigate the relationship between board composition and the likelihood of winning a MBNQA, and how this relationship is related to firm value to answer the following research questions: Is there an appropriate board structure that fits a QM strategy? And furthermore, could this fit be related to firm performance - and thus, shareholder value - during and after the implementation of a QM strategy? By answering these questions we contribute to learning more about how corporate governance, and specifically, board composition can be related to shareholder value.

Under a contingency framework (Drazin and Van de Ven, 1985; Venkatraman, 1989), and borrowing elements from the resource-based view (Barney, 1991), and the cognitive approach of boards (Rindova, 1999), we examine three hypotheses related to directors' expertise. Specifically, we propose that, the presence of the following types of directors is related to the likelihood of attaining quality excellence: i) inside directors (firm specific expertise), ii) industry experts, such as experts in the main object of business operations and directors from related industries, and iii) management experts. Subsequently, we examine the link between firm value and board composition in a QM strategy context.

To examine these hypotheses we employ a conditional logistic regression methodology (Hosmer and Lemeshow, 2000). The unique, hand-collected sample consists of 136 US publicly traded firms: 68 firms that won their first Malcolm Baldrige or Malcolm Baldrige based quality award during the period 1996-2012, and their 68 matching counterparts. To test the first three hypotheses, we use data from the period during which the companies were in their QM implementation phase, specifically, three years before the award-winning year. To test the fourth hypothesis, we employ residual analysis, using data for every year from that year to three years after winning.

The empirical findings indicate that firms that excel in quality have larger boards, and that the likelihood of attaining quality excellence is positively related to the number of outside directors who are experts in

1. See Stiles and Taylor, 1996; Pugliese, Bezemer, Zattoni, Huse, Van den Bosch, and Volberda, 2009 for discussions on the strategic role of directors, and Hillman, Cannella, and Paetzold, 2000; Markarian and Parbonetti, 2007; Coles, Daniel, and Naveen, 2008; Lehn, Patro, and Zhao, 2009; Brickley and Zimmerman, 2010 for empirical studies. 
the main object of their business operations and outside directors with recent experience in a related industry. This is consistent with Coles, Daniel, and Naveen $(2008 ; 2012)$ and Markarian and Parbonetti (2007) who find that complex firms with increased advising requirements have larger boards that include outside experts who enhance the firm's ability to handle complexity. Moreover, we find that certain measures of performance, namely, operating income before depreciation, operating margin (and correspondingly, cost per dollar of sales), as well as Tobin's q and ten-day raw and market adjusted returns are contingent on the fit between board composition and the quality strategy. Referring back to the research questions, the results show that there are indeed elements that make board composition more appropriate for firms pursuing performance excellence, and that are associated with shareholder value in this specific context.

This study contributes to the literature by looking into the corporate governance issues of firms that pursue excellence. By that, we contribute to shifting the corporate governance literature's focus from firms that are in distress, to firms that create value for shareholders. Furthermore, this study highlights the strategic role of the board, and the value creation role of directors, by linking board composition to value creation. ${ }^{2}$ In addition, it contributes to a relatively newly emerging strand of literature in the fields of finance and corporate governance that focuses on directors' expertise (see for example Peterson, Philpot, and O'Shaughnessy, 2007; Dass, Kini, Nanda, Onal, and Wang, 2014; Faleye Hoitash, and Hoitash, 2013, 2014; Minton, Taillard, and Williamson, 2014; Wang, Xie, and Zhu, 2015).

The remaining of the paper proceeds as follows: In section two we present the background and we develop the hypotheses, whereas in section three we present the methodology. We present the empirical results in section four, and we conclude in section five.

\section{Background and hypothesis development}

In this section we form the hypotheses under a contingency perspective, utilizing elements of the resource-based and the cognitive perspective of boards.

2. There is also literature on how board composition can destroy firm value (see for example Faleye, 2007, on how classified boards destroy firm value). 


\section{B. Background and theoretical framework}

\section{Acknowledging contextuality}

The corporate governance characteristics that are related to performance excellence are expected to differ from those related to organizational failure and distress, or from those related to other organizational circumstances (Muth and Donaldson, 1998; Dalton, Daily, and Certo, 2003; Daily et al., 2003). ${ }^{3}$ Hence, a contingency approach to study corporate governance has been explicitly suggested (Muth and Donaldson, 1998). ${ }^{4}$ Acknowledging the contextuality of corporate governance characteristics can reveal a spectrum of roles that directors are called on to play, beyond their assumed monitoring and control roles (Johnson, Daily, and Ellstrand, 1996; Daily et al., 2003). Besides, the economics of director selection, as well as director performance are more complex than the categorization of directors into independent, inside, and gray (Coles, Daniel, and Naveen, 2014). Moreover, findings of a stream of studies on the composition of the board of directors that acknowledge contextuality, reveal that the monitoring and strategic roles of directors are neither contradictory nor mutually exclusive but can instead be complementary and executed simultaneously (Adams and Ferreira 2007; Brickley and Zimmerman 2010).

Specifically, Boone, Field, Karpoff, and Raheja (2007) conclude that board size and composition vary with environmental as well as organizational variables. In a previous study, Hillman, Cannella, and Paetzold (2000), by departing from the widely used, agency theory

3. This focus of the corporate governance literature on organizational failure and distress is cited as the reason why the agency model is used more than any other theoretical framework in the corporate governance literature (Muth and Donaldson, 1998; Dalton et al., 2003; Daily et al., 2003). When an organization is in distress, the interests between principals and agents are likely to diverge, since this is a situation in which agents may become more opportunistic (Muth and Donaldson, 1998). In support of this, Charitou, Lambertides, and Trigeorgis (2007) detect earnings management prior to bankruptcy for firms with insufficient monitoring. To protect the shareholders' interests in such cases, more monitoring and control is needed, thus suggested corporate governance mechanisms tend to be agency based (Muth and Donaldson, 1998).

4. Contingency theory is considered to be one of the most widely used theoretical approaches to study organizations (Scott, 1998). The central philosophy behind this is that there is no best way to organize a corporation, and that, instead, the optimal course of action is contingent (dependent) upon the internal and external situation (Scott, 1998; Donaldson, 2001). A few recent studies in the field of corporate governance have explicitly taken this path (see Boyd, 1995; Yin and Zajac, 2004). 
based, manichaeistic inside/outside categorization of directors, and using a taxonomy of directors based on the resources that each director can bring to the firm, show that board composition changes to reflect the needs of a sample of US airline firms going under deregulation. They conclude that the directors act primarily from a resource dependence perspective by providing the firm with valuable linkages, knowledge, and information through their individual expertise and attributes (Hillman et al., 2000). Along the same lines, Masulis, Wang, and Xie (2012) find that the contribution of foreign independent directors (FID) is positive when the firm's operation in the FDI's home region is important, but negative otherwise. In addition, Daniel, McConnell, and Naveen (2013) find that firms with operations in countries dissimilar to the US in terms of legal regime, language, trust, and religion tend to include "dissimilar" foreign directors on their boards, and the value of such directors depends on the degree of "dissimilarity".

Furthermore, according to Coles et al. $(2008 ; 2012)$ and Lehn, Patro, and Zhao (2009) the board is shaped according to the complexity of the firm's operations. More specifically, Lehn et al. (2009) argue that the size and composition of boards are determined by trade-offs between valuable information brought by additional directors versus coordination and free-rider costs. Moreover, jointly addressing directors' monitoring and advisory roles, Linck, Netter, and Yang (2008) find that board composition across firms depends on the costs and benefits of the monitoring versus the advising roles of the board. Finally, Markarian and Parbonetti (2007) also find that the composition of the board with respect to directors' expertise varies with the firm's complexity.

These studies collectively suggest that a universally optimal board composition does not exist. The effectiveness of the various alternative board structures is contextual and contingent on the organization's strategic needs. The possible contingent superiority of one governance structure over another could depend on its fit with the organization's strategy (Yin and Zajac, 2004).

The fit between board composition and quality management strategy

We adopt a contingency approach to explore the relationship between quality excellence and board composition. ${ }^{5}$ The proposition that a fit

5. An obvious source of correlation between board structure and the likelihood of 
must exist between an organization's structure, processes/procedures and its context is central to contingency theory (Venkatraman, 1989; Donaldson, 2001). In this study we conceptualize fit as a theoretically defined matching between the quality management (QM) strategy and board composition (see Drazin and Van de Ven, 1985; Venkatraman, 1989; Ensign, 2001); that is, we hypothesize that if the strategy - in this context, QM strategy - matches board composition, this is positively related with the likelihood of QM success, and furthermore, with shareholder value.

Borrowing elements from the resource-based view (Barney, 1991), we specify "matching" in the QM context based on the resource needs of a firm that pursues a QM strategy (henceforth "QM firm"). These needs, according to the literature, determine what types of directors would be more appropriate for the given context (Hillman et al., 2000; Markarian and Parbonetti, 2007). Because according to Wruck and Jensen (1994), a QM strategy is a very information intensive strategy, QM firms are considered to be "complex firms" under the Jensen and Meckling (1976) definition, and they have increased advising requirements (Coles et al., 2008; 2012). ${ }^{6}$ The advisory capability of directors has been linked with directors' expertise (Rindova, 1999; Faleye et al., 2013; 2014). In this study we are specifically interested in the expertise that would provide directors with the ability to make sound decisions pertaining to the QM strategy.

winning a quality award would be the connection of board members to members of the Examiners' committee of the award givers. However, we excluded this possibility since it is stated clearly in the "Disclosure of Conflicts of Interest" section of the Examiners" Code that every examiner is asked to provide detailed information that allows the award giver to determine conflicts of interest with applicants. This information is used to assign Examiners to applications. Moreover, the Examiners sign an official declaration, and there are consequences in case of misstatement. Examiners are required to update their records periodically throughout their appointment. Furthermore, every year there is a public list of the about three hundred and fifty members of the Examiners' Board on the National Institute of Standards and Technology (NIST) Website.

6. According to Wruck and Jensen (1994), QM strategy implementation is very information intensive, as it requires inputs from all levels of organizational structure. In order to prevent QM failure is essential to collocate the "decision rights" pertaining to QM - which at the strategic level are owned by the board of directors - with the "specific knowledge" required for taking decisions for this strategy (Wruck and Jensen, 1994). That could be achieved by placing on the board of QM firms directors that have the ability to take decisions pertaining to this strategy. 


\section{Director expertise}

Expertise pertaining to boards falls into two categories: i) firm specific knowledge and skills, and ii) general expertise which is necessary to enable directors to make significant contributions to strategy (Rindova, 1999). The former refers to an intimate understanding of the firm's operations and internal management issues; the latter refers to knowledge pertaining to a specific domain, awareness of specific issues in it, and skills that can contribute to solving those issues (Sullivan, 1990); it can refer both to the traditional domains of business expertise, as well to domains specific to the firm's relationship with its environment (Rindova, 1999). With the first three hypotheses we examine these categories in a QM context.

\section{Firm specific expertise}

Firm specific expertise is necessary to assess managerial competence and to evaluate the strategic desirability of initiatives regardless of their short-run performance outcome (Baysinger and Hoskisson, 1990). The importance of this for QM emerges from the fact that often, QM firms have to sacrifice short-term results in favor of the QM strategy (Hendricks and Singhal, 1997). Managers are the main sources of firm-specific information, and since outside directors do not possess this knowledge, this information is brought into the boardroom by including executive ("inside") directors on the board (Fama and Jensen, 1983; Baysinger and Hoskisson, 1990). Thus, because they have access to inside information, inside directors are in a better position to perform an oversight function based on a system of strategic control, and evaluate top management (Markarian and Parbonetti, 2007). Furthermore, executive directors have an enhanced understanding of the firm's strategy. This makes them more emotionally attached to the strategy than outside directors are (Baysinger and Hoskisson, 1990; Chatterjee, 2009). For these reasons, executive directors can be valuable as part of a QM firm's board of directors.

Moreover, the involvement of top management in QM strategy decisions on the board level enhances top management's commitment to QM-related decisions; top management commitment is a widely cited factor for QM success (Soltani et al., 2008). Furthermore, the shifting of responsibility to management required by QM calls for the analogous empowerment of the management (Soltani et al., 2008). That can be 
achieved by the representation of management on the board of directors (Muth and Donaldson, 1998). ${ }^{7}$

The above discussion leads to the following hypothesis:

H1: The number of inside directors on the board is positively related to the likelihood of QM success.

\section{General expertise}

The most widely researched area of directors' expertise is financial expertise and its relationship with corporate financial decisions, financial performance, and the firm's access to funding (see for example Agrawal and Chadha, 2005; Defond, Hann, and Hu, 2005; Güner, Malmendier, and Tate, 2008). Several studies have also investigated other types of expertise in specific contexts; for example, Hillman et al. (2000) find that there is a greater likelihood of certain types of "support specialists" (experts) - namely directors with legal and financial expertise - to be appointed as replacements on the board of US airline firms during regulation - than during deregulation - of the US airline industry. Furthermore, Markarian and Parbonetti (2007) find that internal complexity (defined as the complexity related to rapid technological change) is related to the presence of "support specialists" - in their case specialists in the specific industrial sectors in which the firm operates. Recent studies focus on the industry related expertise of directors (see for example Drobetz, Von Meyerinck, Oesch, and Schmid, 2014; Dass et al., 2014).

In this study, we identify the types of general expertise relevant specifically to QM. Namely, we examine industry expertise, and more specifically: expertise in the firm's main object of business operations,

7. On the other hand, empowering the management by increasing its representation on the board has been highly criticised by scholars who ascribe to the agency theory school of thought and view the board mainly as a monitoring and controlling devise (see for example Weisbach, 1988; Byrd and Hickman, 1992; and Cotter, Shivdasani, and Zenner, 1997); however, the presence of insiders is not necessarily at the expense of governance functions (Boumosleh and Reeb, 2005), as most recent research revealed that inside directors too, can serve as good monitors because they have access to superior information, and a better understanding of the actions of the CEO. Furthermore, there is some evidence that boards dominated by outsiders can affect performance negatively (Agrawal and Knoeber, 1996; Bhagat and Black, 2002). Once more, results are mixed; it seems that the impact of inside directors could also be contextual; it is possible that the direction and magnitude of the impact of inside directors is contingent on the context and it should be examined as such. 
and related industries expertise, and also expertise in management. Below we present the rationale for examining these specific types of expertise.

Industry expertise: Directors who have recent experience from being executives or directors at other companies of the same industry, or of upstream/downstream industries can provide useful resources in the form of insights and know-how pertaining to the firm's products and services. Directors with industry expertise have the capacity to offer better inputs into strategic decision-making, because of their deeper understanding of the industry and because they have superior information regarding the industry through connections (Faleye et al., 2014). Furthermore, these directors can provide industry insights and know customer and supplier needs (Dass et al., 2014). According to the evidence, such directors significantly benefit firm value/performance, especially in cases with severe information gaps, and they contribute in handling industry shocks and shorten cash conversion cycles (Dass et al., 2014). Due to the customer-oriented nature of QM programs and due to the information intensiveness of QM strategy, these characteristics are expected to be important. Thus, the next hypothesis becomes:

H2a: The number of industry experts on the board is positively related to the likelihood of QM success.

Furthermore, directors with expertise in the firm's main object of business operations could help the firm strengthen its competitive advantage. This is critical for firms that aim quality excellence due to the customer-oriented nature of QM programs (Mele and Colurcio, 2006). For complex firms, intellectual capital and technological know-how are crucial for building a competitive advantage (Makadok, 2001; Markarian and Parbonetti, 2007). Complex firms benefit from a board that includes "support specialists", who are in a position to incorporate knowledge and provide companies with expertise, and knowledge that support strategy formulation and advise the management (Markarian and Parbonetti, 2007). These directors can contribute to capability building, i.e. to the ability of a firm to internally build resources and competencies that lead to competitive advantage. In addition, such directors are likely to have a genuine interest in the firm's main object of business operations. This would make them more engaged in the decision making process (Rindova, 1999). 
$\mathrm{H} 2 \mathrm{~b}$ : The number of directors with expertise in the firm's main object of business operations on the board is positively related to the likelihood of QM success.

Management expertise: Quality management is a systematic management process that requires expert consulting on management issues, thus the other type of expertise we examine is expertise in the field of management. ${ }^{8}$ Quality management programs are essentially efficiency improvement initiatives that impose major reorganization and restructuring using the rhetoric of quality (Wruck and Jensen, 1994). Reorganization and restructuring efforts benefit from directors who are experts in management issues (Markarian and Parbonetti, 2007). Such directors may as well ignite a QM strategy initiative. Moreover, directors who have management expertise are experts in systematic decision-making and problem solving (Hillman et al., 2000). Furthermore, management experts can provide alternative viewpoints about internal and external issues, and they posses expertise related to the markets and the competitive environment (Hillman et al., 2000; Markarian and Parbonetti, 2007). For this reasons, we hypothesize that management expertise and QM success are related:

H3: The number of management experts on the board is positively related to the likelihood of QM success.

\section{Assessing the relationship between the fit between quality management success and board composition}

As mentioned before, the relationship between QM success and firm performance is very well established in the literature. In this study, we focus on whether performance is contingent on the fit between board composition and QM. Evidence of a congruent relationship between board composition and the likelihood of quality award winning can be considered as adequate evidence of the existence of a fit (Venkatraman, 1989); however, demonstrating a contingent relationship between the fit and performance would further support the argument for the existence of a fit between the two. We hypothesize that such a contingency exists,

8. Of course, including experts in management on the board of directors is not the only way to bring quality management expertise to the organization: the use of expert systems specifically designed for quality management has also been discussed as an alternative to appointing human experts (Franz and Foster, 1992). 
and that the degree of "fit" between board composition and the likelihood of quality award winning is positively related to firm performance.

H4: Firm performance is contingent upon the "fit" between board composition and the likelihood of winning a quality award.

\section{Methodology}

To examine the interplay between board composition, quality excellence, and value, first, we assess the congruent relationship between quality management (QM) and board composition using a conditional (matched-pairs) logistic regression approach. Next, we employ residual analysis, to assess the contingency of firm performance on the fit. In this section we discuss the sample and matched sample definition and selection, we present the empirical models, and we describe the data collection process.

\section{A. Sample selection}

To proxy the successful implementation of a QM strategy we use the winning of the prestigious Malcolm Baldrige National Quality Award (MBNQA) given annually by the National Institute of Standards and Technology (NIST) and also State quality awards that are explicitly based on the Baldrige award criteria. ${ }^{9}$ Several previous studies have used the winning of quality awards to proxy effective quality practices (Hendricks and Singhal, 1996; 1997; 2001b). ${ }^{10}$ Following Hendricks and

9. The MBNQA is the only formal recognition of performance excellence given by the President of the United States. Similarly, the State Quality Awards that are explicitly based on the MBNQA are given by the Governor of each State. The awards are given based on six criteria, namely: (1) Leadership, (2) Strategy, (3) Customers, (4) Measurement, Analysis, and Knowledge Management, (5) Workforce, (6) Operations, and (7) Results. Up to eighteen quality awards may be given annually by each award giver; they cover six eligibility categories: manufacturing, service, small business, education, health care, and non-profit. In this study we focus on for-profit publicly traded companies for which financial data is available.

10. See Hendricks and Singhal (2001b) and York and Miree (2004) for a discussion on the superiority of Malcolm Baldrige based quality awards as a proxy for quality management success. Other studies have used ISO 9000 certification as a proxy for effective quality management implementation (Nicolau and Sellers, 2002; Corbett et al., 2005). 
Singhal (1996), we consider a company that has won a MBNQA or an award officially based on its criteria to be a company that has succeeded in its QM strategy implementation.

One might reasonably ask whether firms that are not included in the award winners lists - either because they never applied or because they applied and did not win - are considered to be "QM failures". Since the Code of Examiners protects the confidentiality of the lists of applicants for the awards, we are not in a position to know which companies applied but failed to get such an award. Other companies that are not included in the award winners lists are companies that for various reasons chose not to apply for such an award in the first place. Theoretically, companies that are not included in the award winners' lists belong in one of the following categories: (i) companies that chose not to pursue a QM strategy in the first place, or (ii) companies that they do have a QM strategy but they do not consider it to be successfully implemented yet, or (iii) companies with successfully implemented quality strategies that simply chose not to apply for such an award, or (iv) companies that consider themselves to have a successfully implemented quality strategy and have applied for an award but did not succeed in winning one. Let us now examine separately each category, along with the implications of not having a "losers list" for the analysis. Firstly, taking into consideration that the application process itself is costly, both in terms of paying fees, as well as in terms of effort, and that the awards are very competitive as they are very limited in number, we could agree that companies in categories (i) would not apply, as this would be pointless - they have nothing to gain from applying.

Firms in category (ii) might apply only in order to receive consulting to assist them with their QM journey (if just hiring consultants and using the guidance from the criteria is not enough for them) - however, firms with less mature QM implementation, will probably start receiving supplier quality awards (Hendricks and Singhal, 2001b), so in the analysis, we exclude companies that won supplier awards from the matching sample to weed out such firms, as they could introduce noise to the sample.

Concerning category (iii), it would be reasonable to assume that, a company that has taken the conscious effort to successfully implement a QM program going through its difficult and costly requirements (according to Hendricks and Singhal, 1996), would want to signal to the market this success. This is because of the real economic benefits that emerge from signaling the winning of a quality award (Hendricks and 
Singhal, 1996; Easton and Jarrell, 1998; Hendricks and Singhal, 2001a; Nicolau and Sellers, 2002, Przasnyski and Tai, 2002, Corbett et al., 2005). Winning a quality award acts as a market signal over and above the customers' judgment about the quality of a company's products and services, as this was demonstrated by Hendricks and Sighal (1996) with an events study. However, some firms may judge that they have some other strong point that will signal to the market the same message, for example, the firm may have a top brand; brand equity is found to be related to perceived quality (Yoo, Donthu, and Lee, 2000). Therefore, these firms may choose not to go through the MBNQA process, thus they will be missing from the sample. Yet, one could argue, that these firms would be of interest to us, because we are after all, investigating performance excellence, and award winning is just a proxy. But to the degree that some successful firms choose not to apply - and thus not included in the sample but perhaps in the matching sample instead, this would only make the data noisier, and thus, making it harder to uncover the relationship between board composition and quality excellence. Furthermore, there is always the concern that the characteristics of the board themselves may be affecting the probability of both applying for, and winning the award, in which case the proxy could be simply measuring this.

Finally, concerning category (iv) the companies that applied for such an award but did not make the winners' list, are thought to be companies that self-selected themselves into the applicants' list based on a strong belief that they have successfully implemented a QM strategy - that they may have, but still do not win, as the awards are very competitive and few in number. Again, these companies may already be winning supplier awards, and thus, unlikely to end up in the matching sample. Again, if they did end up in the matching sample, this would make the data noisier and work against finding a relationship between QM and board composition.

The universe of award receivers consisted of 3436 award receiving units (divisions or whole organizations). ${ }^{11}$ These were gathered from the

11. According to (Hendricks and Singhal, 2001), it could be the case that the award receiver is only a fraction of the organization (e.g. a division or a particular geographical site of an organization) and not the whole organization. However, the analysis conducted is for the whole organization, since corporate governance and financial data are reported company-wide; still, this should create no problems as it would only make the tests more conservative, in the sense that the effects of the award must be strong in order to be detected in a sample with many multi-site companies with only one awarded site (Hendricks and 
lists provided online by NIST and by the official Website of each State's quality council. From these, we selected the awarded units that belonged to publicly traded companies at the point they received the award. The final sample consists of 68 publicly traded firms that won a quality award for the first time during 1996-2012. The process is summarized in table 1.

\section{B. Matching sample}

As a next step, we match the 68 sample firms with 68 appropriate control firms. An "appropriate control firm" in this case would be a firm that is not successful in the implementation of its QM strategy.

Candidates for the matching sample would come from category (i) as this is described in the previous sub-section. Companies from any other category would have introduced noise in the samples for the reasons described previously. In order to capture only companies from category (i) and weed out the rest, we scrutinize any matching firm candidate and if it has won quality awards of any kind we exclude it from the matching sample.

Further, following Hendricks and Singhal (1997), we impose the following additional criteria for matching firms: Each matching firm must have (1) the same country of incorporation (all US), (2) accounting data available over at least the same time period as its award winning firm counterpart, (3) fiscal year end in January to May (June to December) if its award winning counterpart has a fiscal year end in January to May (June to December), (4) at least the same 2-digit SIC code, and (5) similar size as measured by the book value of assets at the fiscal year-end before the winning of the quality award, with the constraint that the ratio of the book value of assets of the control and award winning firm is always less than a factor of three. ${ }^{12}$ Initially, it was possible to match only 66 of the sample firms; two companies could

Singhal, 2001). Furthermore, in the final sample, we counted fifty-seven instances out of sixty-eight where the award receiver is the whole organization.

12. "Factor of three" means that the matching firm's book value of assets should be by an amount larger than the one third of the award-winning firm's book value of assets, but smaller than the triple of the award-winning firm's book value of assets. When we attempted to use even a slightly lower factor (i.e. stricter matching) this left us with more than half of the sample firms unmatched. Therefore, a factor of three is the best we can do in order to have a usable sample size. This is also the reason we also include firm size as a control variable in all the models. 
TABLE 1. The quality award receivers' sample

A. The selection process

Awards received up to April 2014 (by divisions or organizations)

3436 awards

Awards received by publicly traded firms (up to April 2014)

759 awards

Number of publicly traded firms that won those 759 awards

334 firms

Unique publicly traded listed firms that received a quality award during 1996-2014 (April) - Because we require Proxy Statement data for three years before the award;

155 firms we have Proxy Statement data only from 1994 (and depending on the FYE, this could include 1993 in some cases).

Firms that won their first award in 1996-2014 (April)

94 firms

Eliminated due to lack of sufficient financial data such

as performance data

14 firms

Eliminated due to lack of proxy data

12 firms

Remaining usable quality award receivers

68 firms

Year Number of Firms Awarded for the First Time Percentage

B. Time distribution of awards

\begin{tabular}{lcr}
1996 & 3 & $4.41 \%$ \\
1997 & 5 & $7.35 \%$ \\
1998 & 12 & $17.65 \%$ \\
1999 & 5 & $7.35 \%$ \\
2000 & 6 & $8.82 \%$ \\
2001 & 8 & $11.76 \%$ \\
2002 & 5 & $7.35 \%$ \\
2003 & 6 & $8.82 \%$ \\
2004 & 10 & $14.71 \%$ \\
2005 & 2 & $2.94 \%$ \\
2006 & 2 & $2.94 \%$ \\
2008 & 1 & $1.47 \%$ \\
2010 & 1 & $1.47 \%$ \\
2012 & 2 & $2.94 \%$ \\
\hline Total & 68 & $100 \%$ \\
\hline & Continued $)$
\end{tabular}


TABLE 1. (Continued)

\begin{tabular}{lcr}
\hline Industry & Number of Firms & Percentage \\
\hline C. Distribution of awarded firms by industry & & \\
Manufacturing & 36 & $52.94 \%$ \\
Transportation, Communications, Electric, & 6 & $8.82 \%$ \\
Gas, And Sanitary Services & 1 & $1.47 \%$ \\
Wholesale Trade & 5 & $7.35 \%$ \\
Retail Trade & 7 & $10.29 \%$ \\
Finance, Insurance, And Real Estate & 13 & $19.12 \%$ \\
Services & 68 & $100 \%$ \\
\hline Total &
\end{tabular}

Note: This table presents details of the process utilized to collect the sample of the public firms that won a Malcolm Baldrige award or a state quality award explicitly based on the Malcolm Baldrige National Quality Award for the first time between the years 1996-2012, as well as information on the distribution of the awarded firms with respect to the year they received the award, and with respect to the industry in which they belong.

A. This panel presents a summary of the sample selection process. The database consists of 3436 of award receiving divisions/firms, paired with award-providing organizations and the time the award was received. Thus, for example, a firm winning an award from two different award-givers or at two different times has two records. Because of data availability reasons, this study focuses on publicly traded firms, so we were interested to match each division with its parent company. Each award receiver was looked up in the databases of Hoover's Online and Edgar Online (SEC Web site) in order to specify the corresponding parent organization at the time that the division was awarded, and to specify whether the parent organization is private, public, government owned or non-profit. We found that 759 out of the 3436 awards had gone to business divisions that actually belonged to 334 publicly traded firms. The remaining divisions that were excluded belonged to one or more of these categories: private, not-for-profit, government, or military. For a few cases nothing could be found about a division (this was the case for older awards). From these 334 publicly traded firms 155 listed on NYSE, NASDAQ and AMEX received a quality award during 1996-2012 (maybe for the first time, maybe for the 2 nd or the $3 \mathrm{rd}$ and so on). From these, we selected 94 firms that had won their first quality award during 1996-20012. It was verified through the firm's history that these firms had not won any quality awards through any of their other divisions, ever before. From these 94 firms, 26 were eliminated from the sample due to lack of data (14 firms had not sufficient financial data, while 12 firms did not have proxy data available for the time period of interest). Thus, the final sample consists of 68 publicly traded firms that won a quality award for the first time during 1996-2012.

B. This panel presents the distribution of the 68 firms in the sample that won a Malcolm Baldrige National Quality Award or a state quality award explicitly based on the Malcolm Baldrige Award criteria for the first time between the years 1996-2012, with respect to the year they received the award.

C. This panel presents the distribution of the 68 firms in the sample that won a Malcolm Baldrige National Quality Award or a state quality award explicitly based on the Malcolm Baldrige Award criteria for the first time between the years 1996-2012, with respect to the industry in which they belong. 
not be matched due to their large size. Eventually, it became possible to match those two firms after allowing a single-digit SIC code matching, so all of the 68 sample firms were eventually matched. ${ }^{13}$

\section{Empirical model and data collection}

In this section, we present the empirical model, and describe the main variables of interest as well as the control variables. Quality award-winning data were hand-collected as described in the previous subsections (sample and matching sample selection); board characteristics, director characteristics and corporate governance data were hand-collected from proxy statements (form "def 14A") from the Website of the Security and Exchange Commission (SEC); and finally, accounting data were downloaded from the Compustat database, and financial data from CRSP. In addition, award announcements needed for subsequent tests were obtained using Thomson One and Nexis US databases.

At a first stage, to test hypotheses $\mathrm{H} 1, \mathrm{H} 2$, and $\mathrm{H} 3$ we assess a congruent relationship between the likelihood to win a quality award and several board and firm characteristics. The dependent variable is a dichotomous variable that indicates whether a firm has won a quality award or not. Because it is a binary variable, we employ a logistic regression model; moreover, because by construction the sample is not random - but it is rather matched - a conditional (matched-pairs) logistic regression model is utilized (Hosmer and Lemeshow, 2000). The independent variables are dated three years before the winning of a quality award for each company and its matching company. The empirical model is shown in table 4 along with the definition of each variable used in the model. ${ }^{14}$

13. Matching on single-digit SIC is appropriate for large firms since they tend to be more diversified (Hendricks and Singhal, 1997).

14. We effectively study the quality management implementation period. It can take from three to five years to implement a quality management program effectively (Hockman, 1992). Following Hendricks and Singhal (2001b) who assume that QM implementation is effective twelve months before the time of winning the first quality award, by taking data dated three years before the quality award was received, we effectively use data dated two years before the actual effective QM implementation. Though it would have been interesting had we been able to have data dated five or more years before winning the first quality award, three years is the best we can do, given the fact that proxy statement (form "def 14A") data is only available since 1994, covering the years 1993, 1994 and beyond. Thus, should we have required to take into consideration earlier years, the sample size would have shrunk 
The main variables of interest to test $\mathrm{H} 1, \mathrm{H} 2$, and $\mathrm{H} 3$ are the variables representing the number of inside (i.e. executive) directors, the number of industry experts, and the number of experts in management. This information about each director can be found in the curriculum vitae of each director in the proxy statement document (form "def 14A") of each firm.

The number of inside directors is the number of directors that are also employees of the company. The inclusion of insiders on the board has been a controversial issue (see for example Jensen, 1993 and Cotter et al., 1997). Research findings show that the inclusion of insiders on the board once independence has been achieved can be beneficial (Boumosleh and Reeb, 2005). Thus, we examine the role of insiders after controlling for board independence. That is, we multiply the number of inside directors with a dummy variable indicating whether the fraction of independent directors is higher than $50 \%$ or not. ${ }^{15}$

Industry experts consist of experts in the main object of the firm's business operations and directors with experience from related industries. The number of experts in the main object of the firm's business operations is the number of directors that hold a Ph.D. in a field related with the main operations of the firm. The number of directors from related industries is the number of outside directors that have been managers and/or directors in companies of the same four-digit SIC code as the primary industry of the company, during the last five years.

Likewise, the number of experts in management consists of the number of directors that hold a Ph.D. in a management related field (inside and outside, although there were zero inside directors with a $\mathrm{Ph} . \mathrm{D}$. in management, as those were exclusively academics with academic jobs), of the number of directors (inside and outside) that have a Master in Business Administration (MBA) degree, and the number of outside directors that work as management consultants.

Although board composition could be associated with firm value through the board's involvement with the firm's strategy, there is

considerably and analysis would have been impossible.

15. Independent directors are directors that are not employees of the company and not affiliate directors; affiliated directors are directors that are not employees of the company but are former employees, relatives of the CEO, or have significant transactions and/or business relationships with the firm (as defined by Items 404(a) and (b) of Regulation S-X). Directors on interlocking boards (situations in which an inside director serves on a non-inside director's board, as defined by Item 402(j)(3)(ii)) are also defined as affiliates. 
always the question whether it is the board that plays the most important role or the top management, the CEO; the role of the board may be weakened when the firm's CEO is powerful (Faleye et al., 2013), and the rest of the board has less influence on strategic decisions (Golden and Zajac, 2001). For this reason, we control for variables that proxy for CEO power, such as CEO duality and CEO block-holding. Moreover, even though various environmental parameters are controlled for through the matching, it was deemed necessary to further control for factors that according to the literature affect the success of QM implementation. One of the factors that might be affecting the likelihood of winning a quality award is firm size: Smaller firms may be discouraged from embarking on a QM program because of the high upfront costs (Hendricks and Singhal, 2001b). We employ total assets (ln) to proxy firm size. ${ }^{16}$ Additionally, we control for performance (natural logarithm of net sales and ROE) since some studies argue that better performing firms are more likely to win a quality award (see for example York and Miree, 2004). Another factor affecting QM is the degree of firm diversification - it is easier for more focused firms to transfer QM implementation approaches across their uniform business units (Hendricks and Singhal, 2001b). The degree of firm diversification is measured by the Herfindahl index, which is defined as the sum of the ratio of the squared fraction of sales of each business segment to the firm's total sales. The value of this index ranges from zero to one; a low value indicates a more diverse firm while a high value indicates a more focused firm. One more factor we control for is the degree of the firm's capital intensity, whose relationship to QM success could either be positive or negative because on one hand, the high degree of automation in higher capital-intensive firms may have already enabled these firms to have a high degree of inherent process control, making QM process controls easier to implement (Hendricks and Singhal, 2001b). On the other hand, an important component of QM is the implementation of work practices and employees are the driving force for improvements that lead to QM success, and this is expected to be the case in lower capital-intensive firms (Hendricks and Singhal, 2001b). Capital intensity is the ratio of net property, plant and equipment to the number of employees.

16. As stated earlier, firms are already matched by size (total assets). However, in order to be able to match all the firms we use a factor of three to match them, thus further taking into consideration size by including it in the regressions as a control variable was deemed necessary. 
We further control for agency theory parameters; under the agency theory, directors' expertise, knowledge, abilities, and competencies would contribute to quality excellence - and in general higher firm performance - only under the condition that the directors have the incentive to work towards the benefit of the company. Under the agency theory, the alignment of directors' interests with the benefit of the company is primarily achieved through incentive alignment and monitoring. Therefore, we control for mechanisms of incentive alignment (percentage of managerial and directors' ownership of company shares and the natural logarithm of the directors' total compensation); we also control for the intensity of monitoring by shareholders, using as proxy the concentration of company ownership (percentage of largest block of shares held). For the agency theory suggested variables we expect a positive relationship, except for the percentage of largest block of shares held, since large controlling shareholders could have detrimental affects on firm value (Boubaker, 2007). Furthermore, we control for measures of directors' efforts (number of board meetings per year and directors' attendance).

In addition, we control for board size (total number of directors) since according to the univariate comparisons between award winners and non-winners (see table 2), award winning firms are rather bigger in size and have larger boards of directors, as they fall within the Coles et al. (2008) description of firms with increased advising requirements.

\section{Assessing the impact of the fit between quality management success and board composition}

To assess $\mathrm{H} 4$ and to provide further support for the argument for the existence of a fit between board composition and the likelihood of award winning we employ residual analysis, a methodology that has been used in contingency studies to assess the impact of fit on performance (see for example Gerdin, 2005; Gerdin and Greve, 2008). Finding a significant relationship would further support the argument that organizational performance is contingent on the fit between QM and board composition (Venkatraman, 1989). ${ }^{17}$ Effectively, this method examines the interplay of board composition, QM, and performance.

17. Yet, the absence of a relationship between the fit and organizational performance does not necessarily imply the lack of fit (Venkatraman, 1989). 


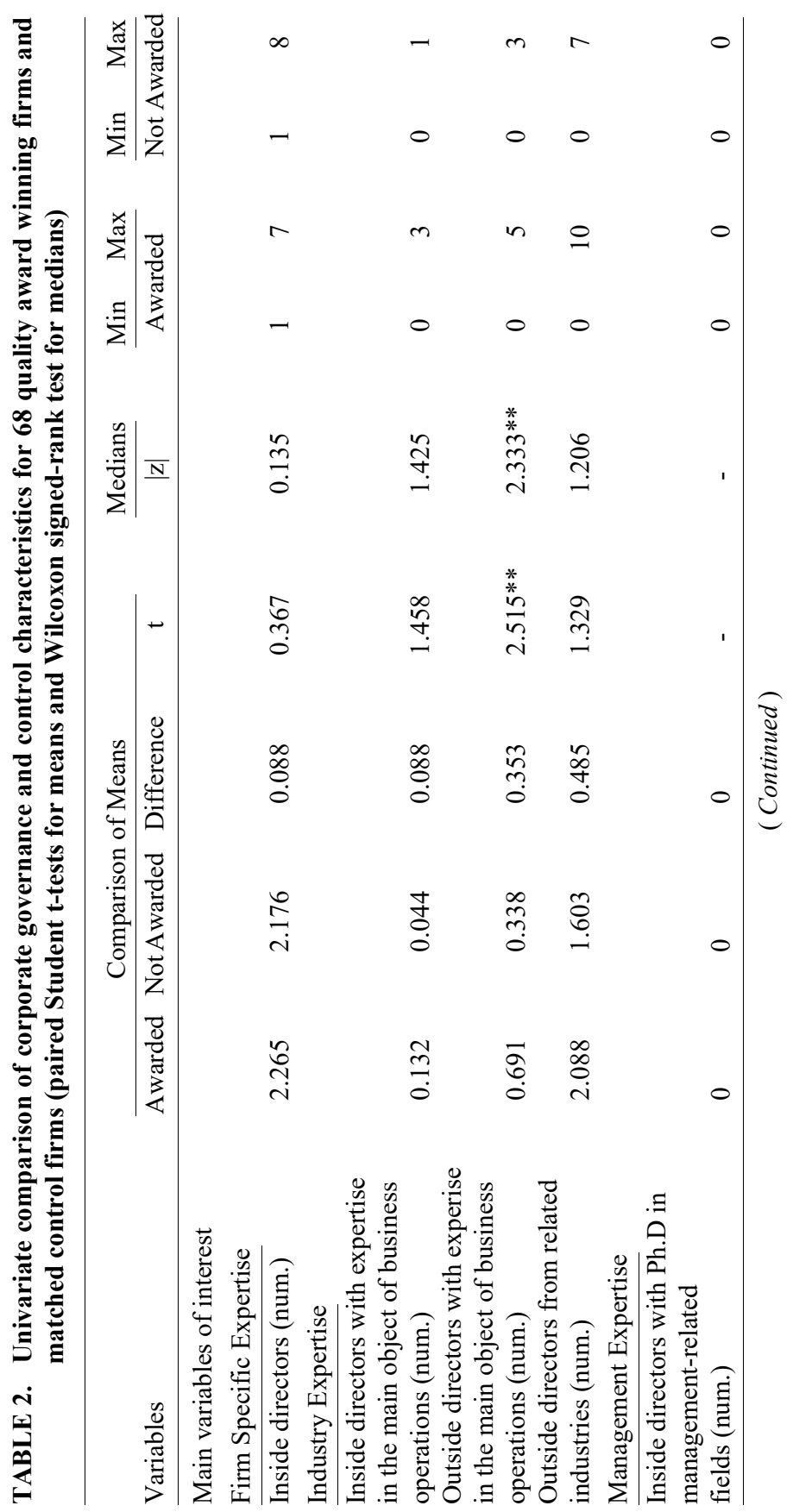




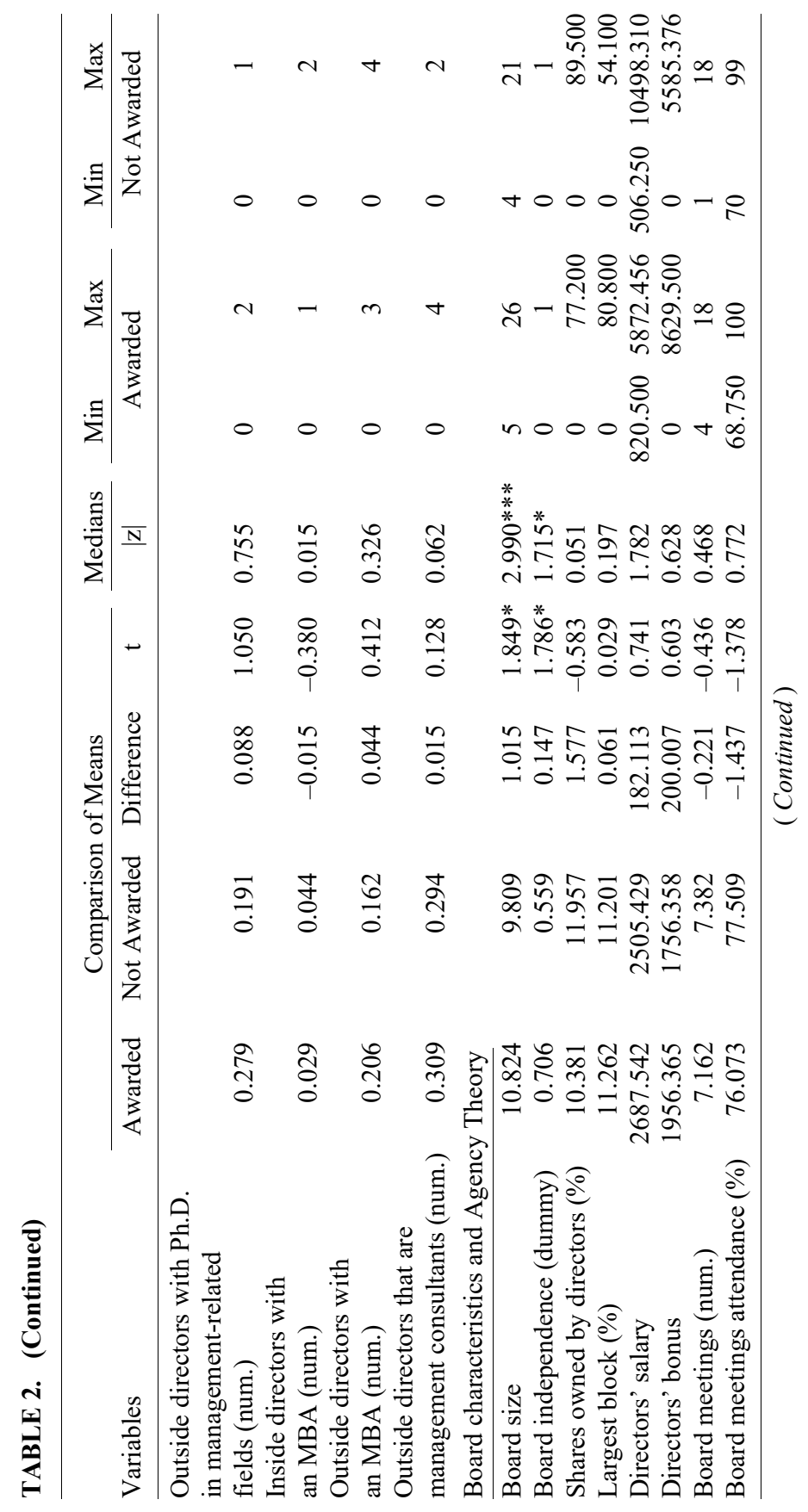




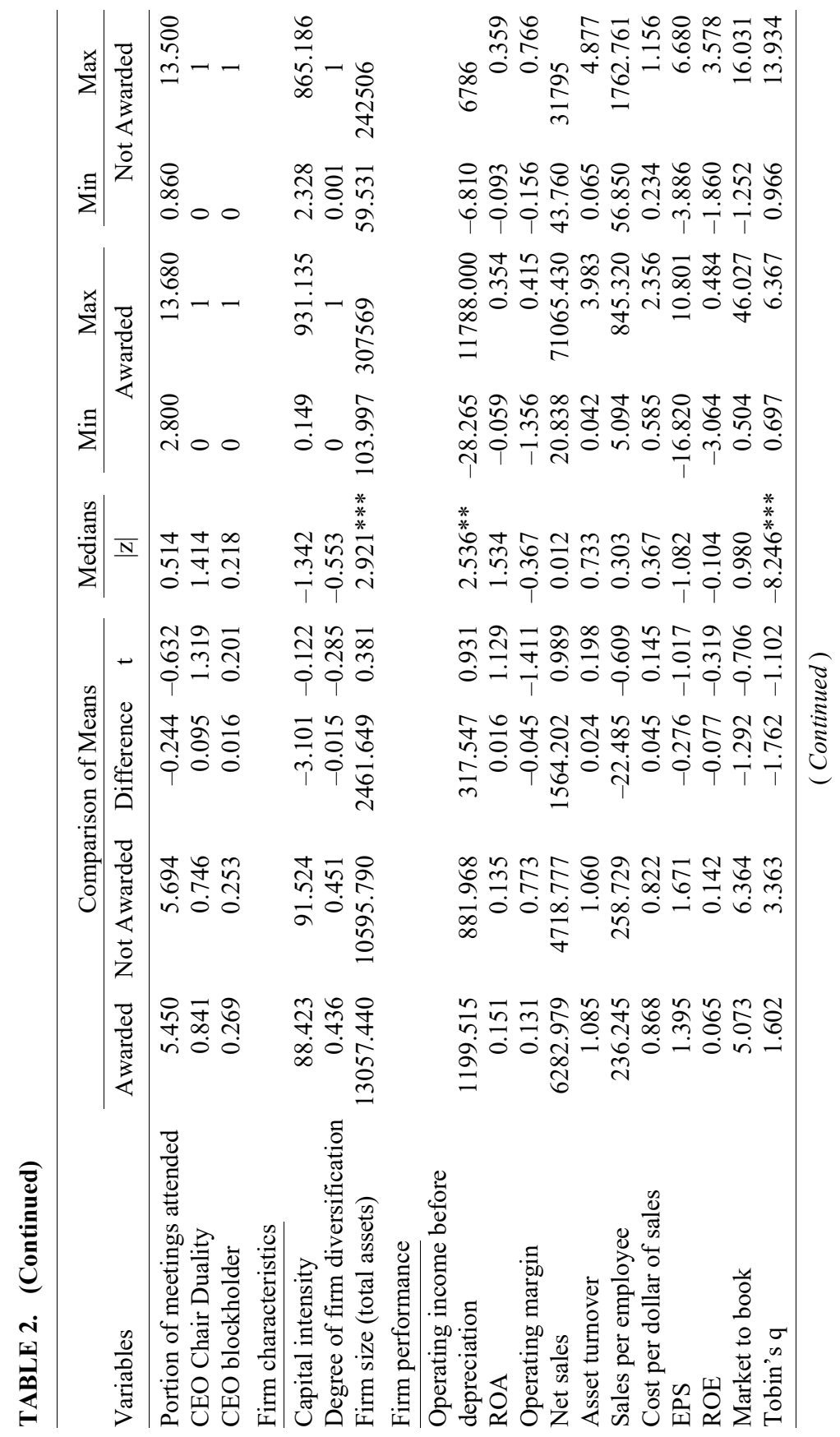




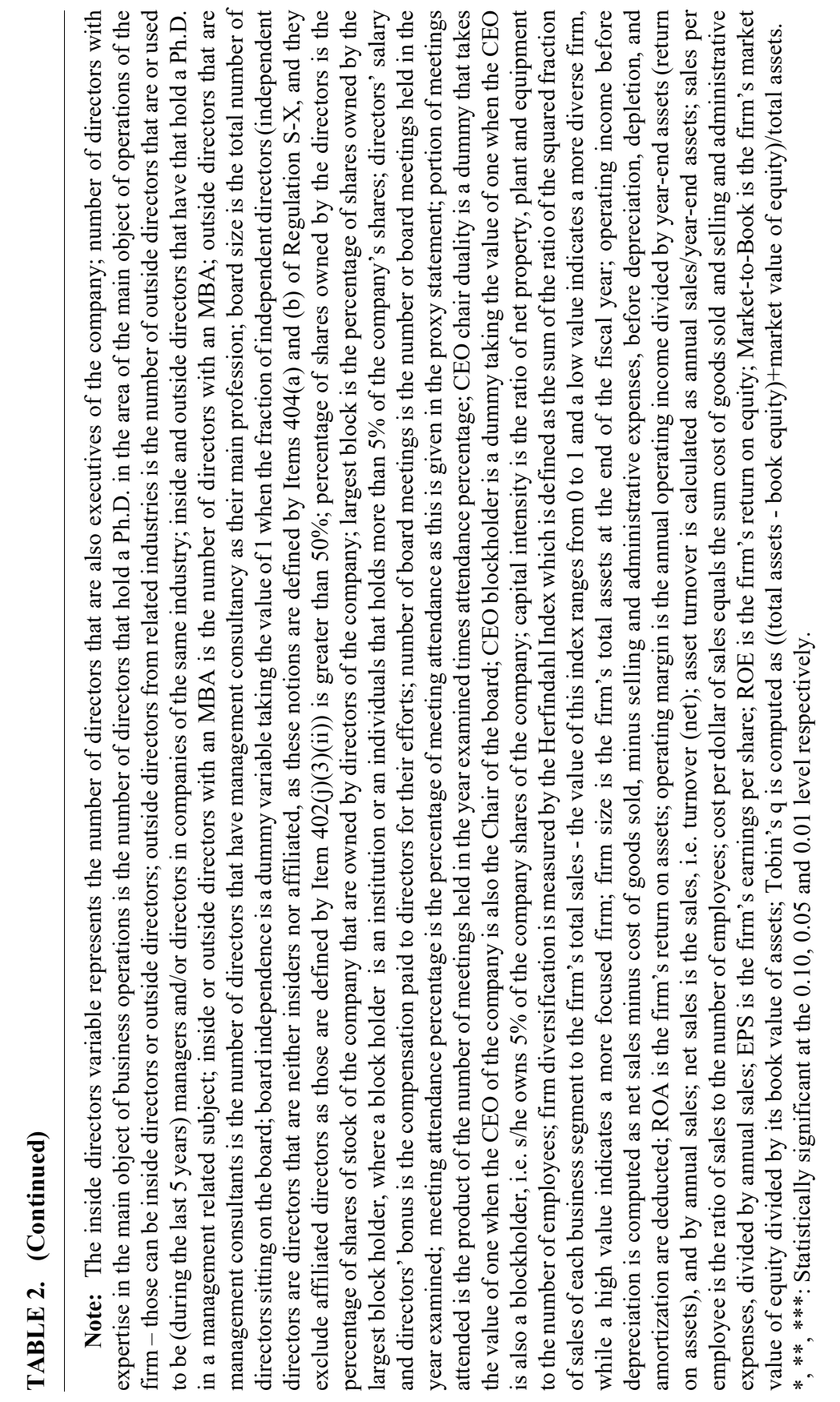


Technically, this is done with a series of regressions to assess the relationship between the absolute value of the Pearson residuals of the conditional logistic regression (of QM success on the board composition and control variables) and a criterion variable, in this case, a different measure of firm performance each time. The Pearson residual in logistic regression is the difference between the observed and the predicted probability of the outcome and is used as a measure of "misfit", i.e. the opposite of fit (Hosmer and Lemeshow, 2000). The Pearson residual, $r$ is defined as:

$$
r=\sqrt{\frac{(1-\hat{\pi})}{\hat{\pi}}}
$$

Where $\pi$ is the probability that the subject identified as the case is indeed the case, and the symbol "^" denotes the estimation of this probability.

We expect that if the fit between QM and board composition is positively related to business performance, then the degree of (absolute) misfit (fit) would be negatively (positively) related with performance. Thus, as a next step in the analysis, several measures of performance are regressed on the quality management-corporate governance fit, i.e. on the Pearson residual.

\section{Performance measures}

We assess the relationship between fit and several measures of performance including profitability, revenue, costs and market performance. These are described in this subsection in detail.

Quality may affect profitability through increased customer satisfaction and increased organizational efficiency, both of which lead to increased revenues; on the other hand QM may initially have an adverse effect on profitability because of implementation costs. Hendricks and Singhal (1997) find that quality award winning firms improve their operating income and also their operating income to assets (return on assets), operating income to sales, and operating income to employees from year from one year before winning a quality award ("year -1") onwards, and that even before year -1 implementation costs do not affect profitability. Following Hendricks and Singhal (1997), as the primary profitability measure we use operating income before depreciation, to capture the economic value (cash flows). This measure has the benefit of being unaffected by the 
method of depreciation, capital structure or the gains or losses from the sales of assets. To control - at least to some extend - for acquisitions and divestitures, we also consider alternative income-based measures such as annual operating income divided by year-end assets (return on assets), and by annual sales (operating margin). The revenue measures we use in this study are net sales, asset turnover (annual sales divided by year-end assets), and sales per employee (annual sales divided by year-end number of employees). The cost measure we use is cost per dollar of sales (sum of annual cost of goods sold and selling, general and administrative expenses divided by annual sales). This also serves as an efficiency measure. Furthermore, we also assess the relationship of fit with several Fortune and Norton and Kaplan measures (see York and Miree, 2004) such as earnings per share, and return on equity. In addition, we assess the impact of fit on Tobin's q and market-to-book ratio. We collected the above data from Compustat.

Moreover, we assess the relationship of fit with cumulative abnormal returns around the award winning date and three-year buy-and-hold abnormal returns. We searched the Thomson One and Nexis US for the award winning announcements for the sample companies in order to specify the exact date an award announcement was made. We were able to find this information for 49 of the award winners. Using EVENTUS we collected cumulative returns (Market Adjusted and Raw) from the CRSP database for the event (award) date, as well as for days " \pm 1 ", “ \pm 2 ", “ \pm 5 ", and " \pm 10 " - the wider windows selected to allow for date misspecification.

\section{Empirical results}

\section{A. Univariate analysis}

First, paired tests for differences in means and medians of the quality award winners sample and its matching sample of non-awarded firms three years before they win a quality award (table 2) indicate that the two samples differ in a number of characteristics: The number of directors with expertise in the firm's main object of operations is higher and statistically significant for award winners, both with respect to the mean and to the median (at the 0.05 level of significance); the size of the board is larger and statistically significant for award winners both with respect to the mean and to the median (at the 0.10 and 0.01 level 
of significance, respectively). These differences between the two groups are consistent with expectations: Quality management (QM) firms are complex firms (Wruck and Jensen, 1994) and as such they have larger boards of directors with more experts (Coles et al., 2008). Award winners also have more independent boards (significant at the 0.10 level, for both means and medians). Wilcoxon non-parametric tests also indicate that there are some differences between the two groups in terms of performance, with awarded firms being larger (at the 0.01 level) and having higher operating income before depreciation and lower Tobin's $\mathrm{q}$ (at the 0.05 and at the 0.01 level, respectively - Wilcoxon), consistent with previous research (Hendricks and Singhal, 1997; York and Miree, 2004). ${ }^{18}$

\section{B. Correlations}

Pairwise Pearson and Spearman correlations between several corporate governance variables, control variables and performance variables for the year three years before winning a quality award are presented in table 3. Winning a quality award is - as hypothesized - positively correlated with the number of outside directors that are experts in the main object of the firm's business operations (Pearson). It is also positively correlated with board size (Pearson), board independence (Pearson and Spearman), and operating margin (Spearman).

\section{Multivariate analysis}

In this subsection, we examine whether a congruent relationship exists between the likelihood of winning a quality award and board composition after we control for other firm characteristics that according to past literature affect the likelihood of obtaining such an

18. Not tabulated: Eighty-two (82) of all the directors in the sample were directors with expertise in the main operations of the company (Ph.D.). Fifty-six (56) of them belonged to companies that won an MBNQA (or one based on its criteria). Two-hundred-and-fifty-one (251) directors had recent experience in related industries, from those, one-hundred-and-one (141) were sitting on the boards of companies that won awards. Thirty-two (32) of all the directors in the sample were directors with a Ph.D. in a management related field and they were all outside directors; nineteen of them belonged to award-winners; five (5) inside directors had an MBA degree, two of which belonged to winners. Twenty-five (25) outside directors had an MBA, fourteen of which belonged to winners; thirty-eight (38) outside directors were management consultants and twenty (20) of them sit on the boards of winners. 


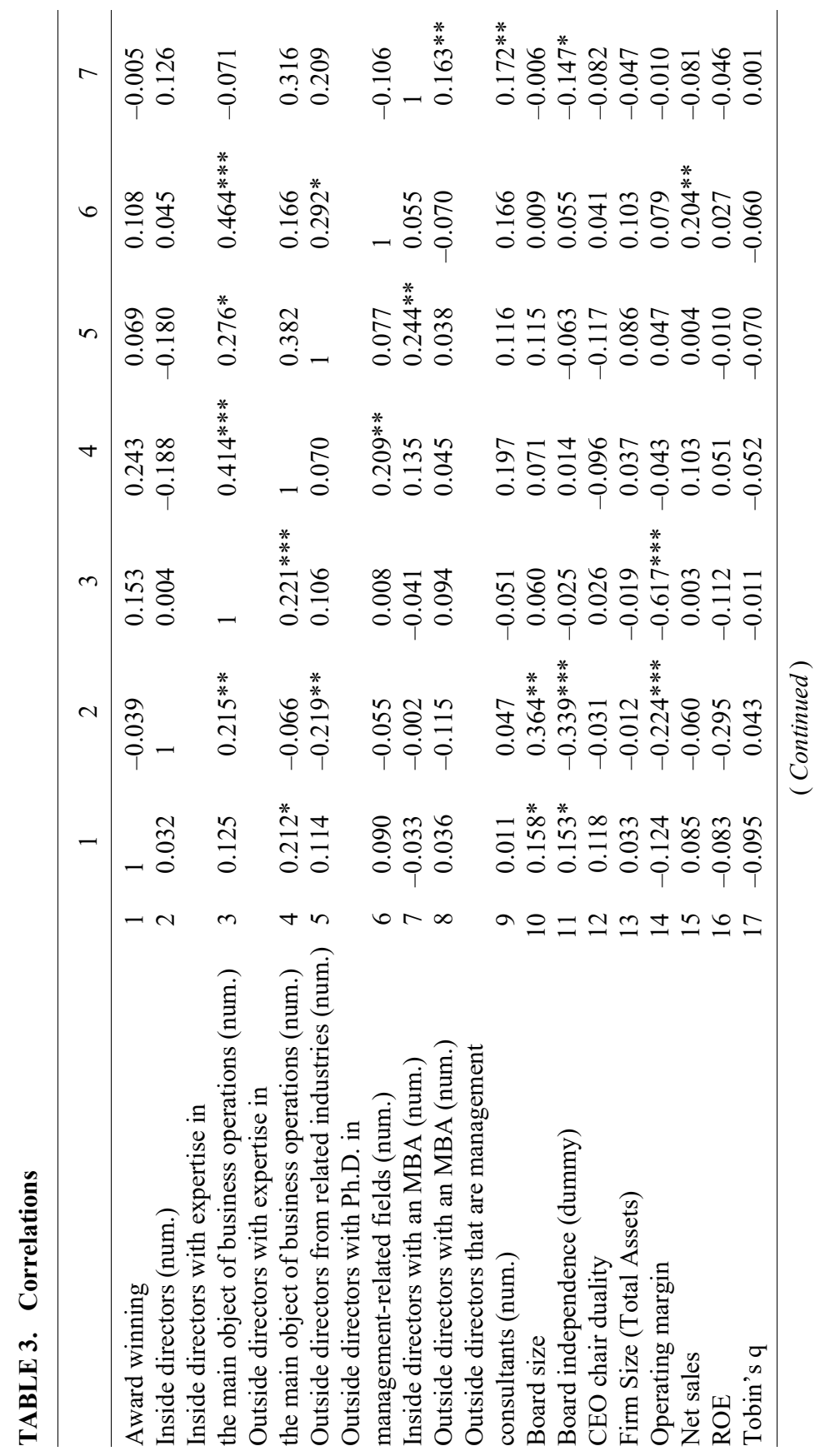




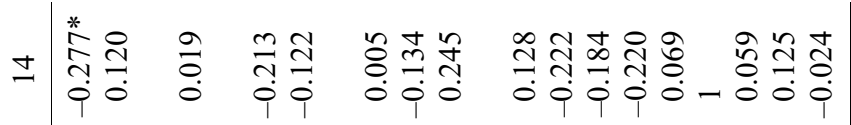

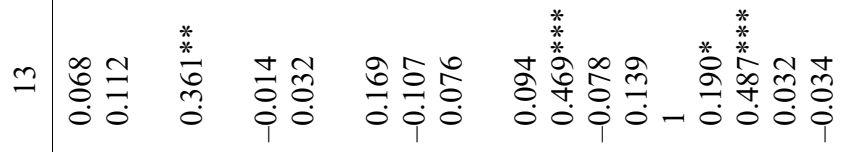

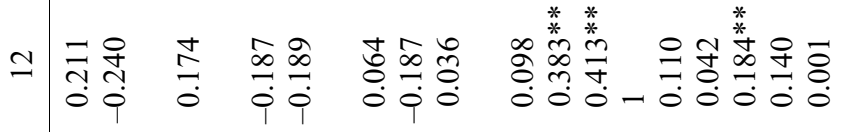

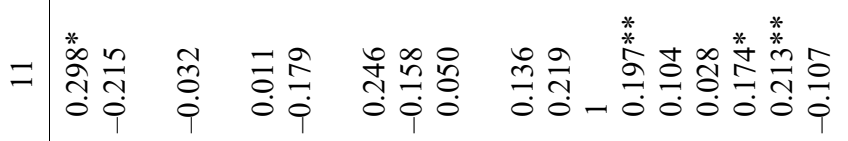

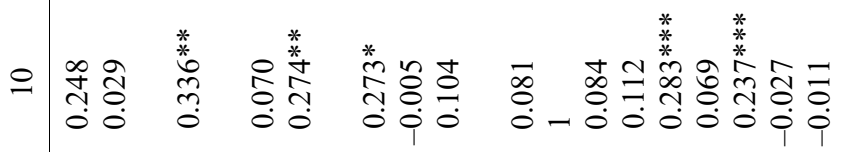

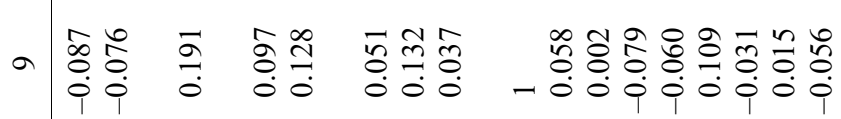

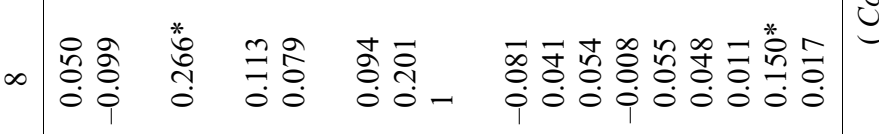

$-n m+n$ or $m$ a ำ

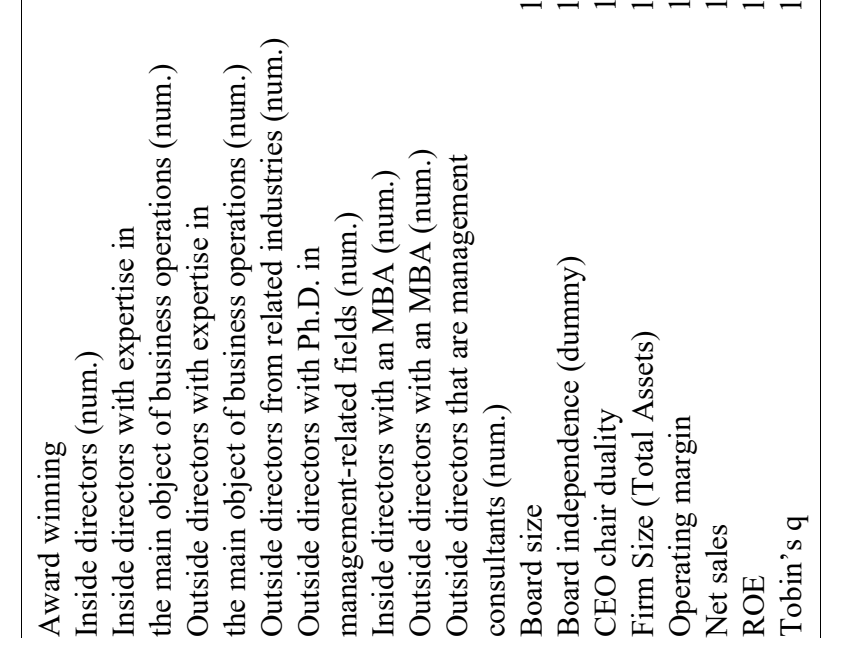




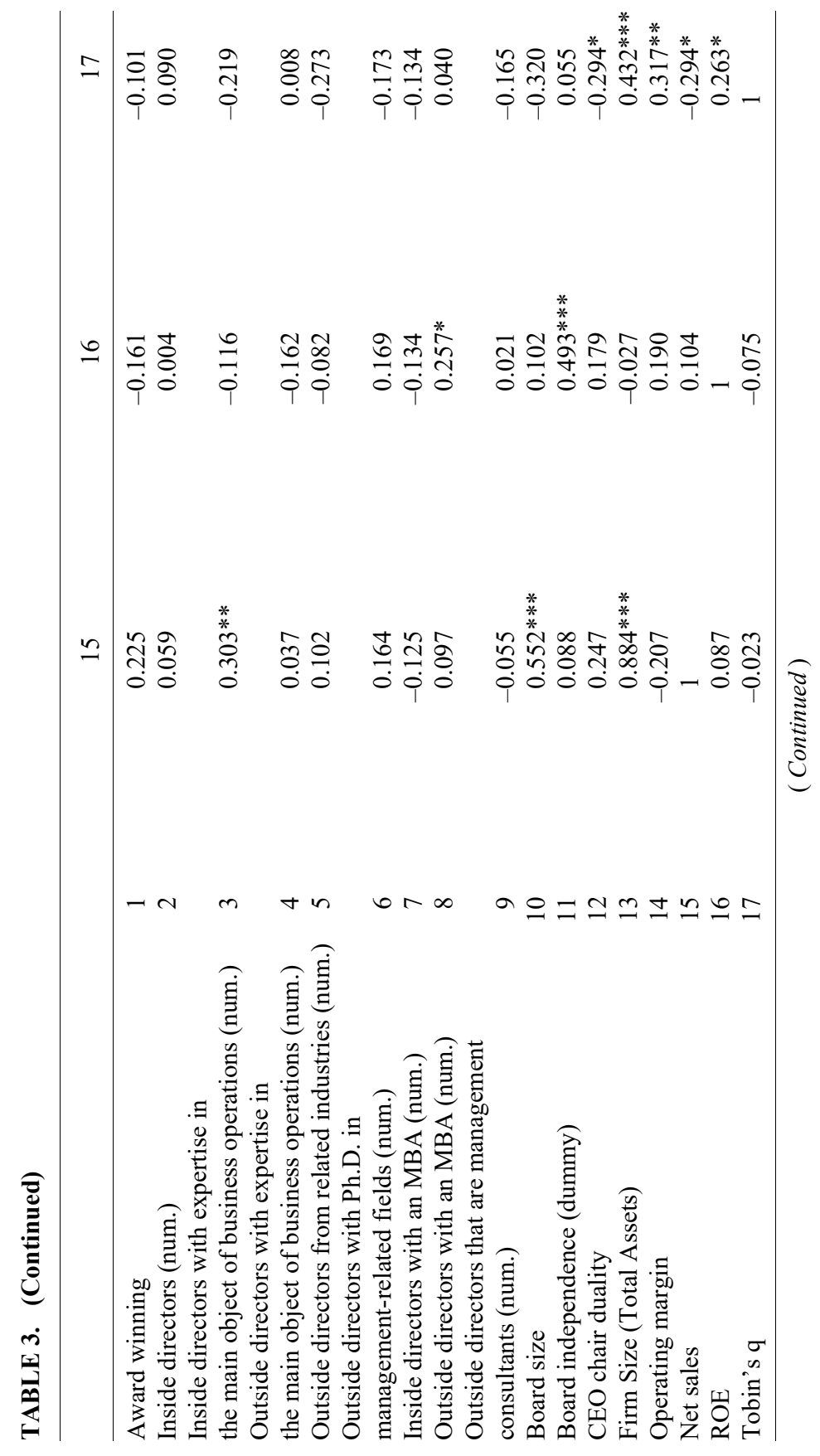




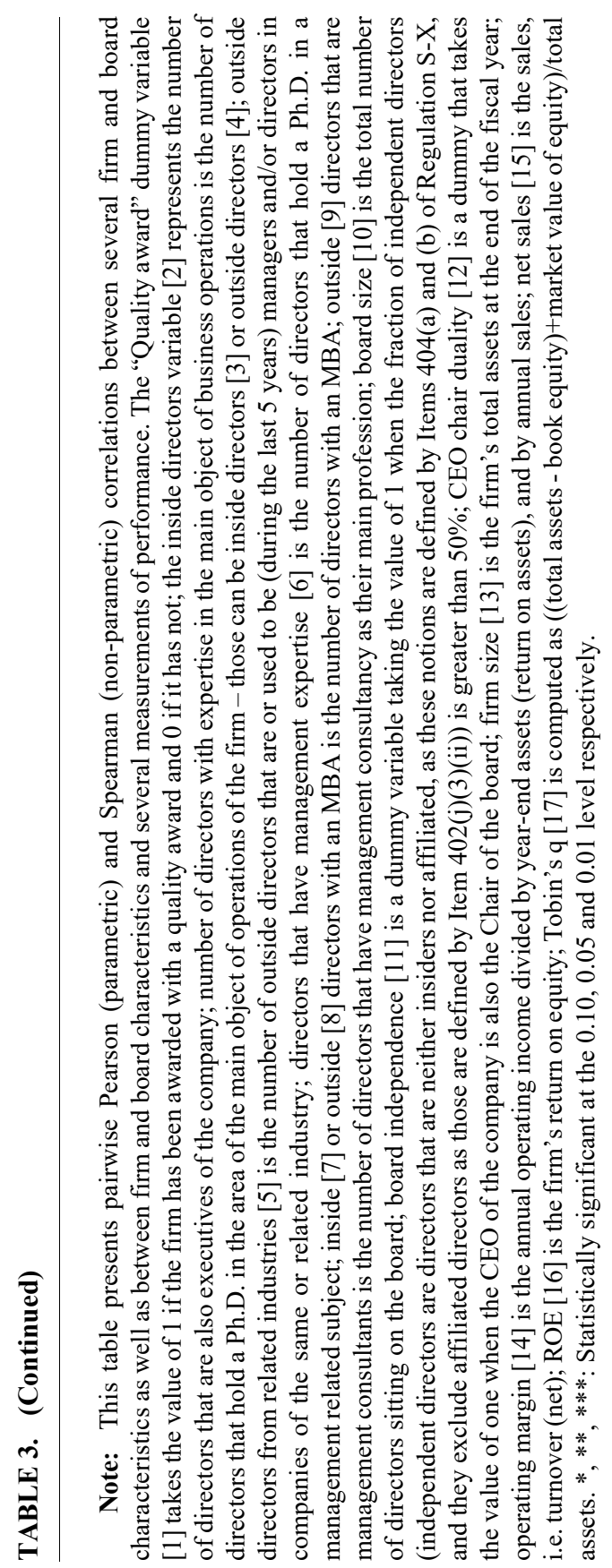


award. We also control for agency theory parameters and other firm or board characteristics. Since by design we use a matched pairs (as opposed to random) sample we use conditional logistic regression models to test the hypotheses. The conditional logistic regression results are shown in table 4. Five models are presented. The dichotomous dependent variable is equal to one for firms that have won a quality award and is equal to zero for control firms in all models.

Model one (tables 4, and 5, panel A), presents the relationship between the dichotomous dependent variable and independent variables suggested by the QM literature to be related with firm performance in QM firms (Hendricks and Singhal, 2001b). In table 4, panel A, the variable representing firm size (the natural logarithm of total assets) appears to be statistically significant at the 0.05 level, and positively related to the likelihood of winning a quality award, with an odds ratio of 2.936. Its marginal effect, according to table 5, panel A, which equals 0.105 , is positive and statistically significant at the 0.01 level; This result is consistent with expectations, since larger firms would be in a better position to implement a QM strategy because of the costs involved (Hendricks and Singhal, 2001b).

Model two (tables 4, and 5, panel A), presents the relationship of the dichotomous dependent variable with corporate governance variables, as those are described in section III, part C. Board independence and board size appear to be positively related to the likelihood of winning a quality award in table 4, panel A (with odds ratios of 2.876 and 1.368, and significant at the 0.10 and 0.05 levels, respectively). The marginal effect of board size (0.026) is positive and statistically significant at the 0.10 level (table 5, panel A). This is consistent with Coles et al. (2008) who claim that complex firms with increased advising requirements have larger boards of directors with more outside directors. The marginal effect of firm size (0.069) is also statistically significant at the 0.01 level (table 5, panel A).

In model three (tables 4, and 5, panel A), we remove the variables that pertain to ownership, compensation, and meetings - as while statistically insignificant, keeping them in the model reduces the sample - and we combine the two groups of independent variables (both the QM variables and the remaining corporate governance variables) in the same model. Results show that board independence, board size and firm size are positively related to the likelihood of winning a quality award with odds ratios of $2.233,1.258$, and 3.083 , and at the $0.10,0.05$ and 0.10 levels of significance, respectively (table 4 , panel A). The marginal 


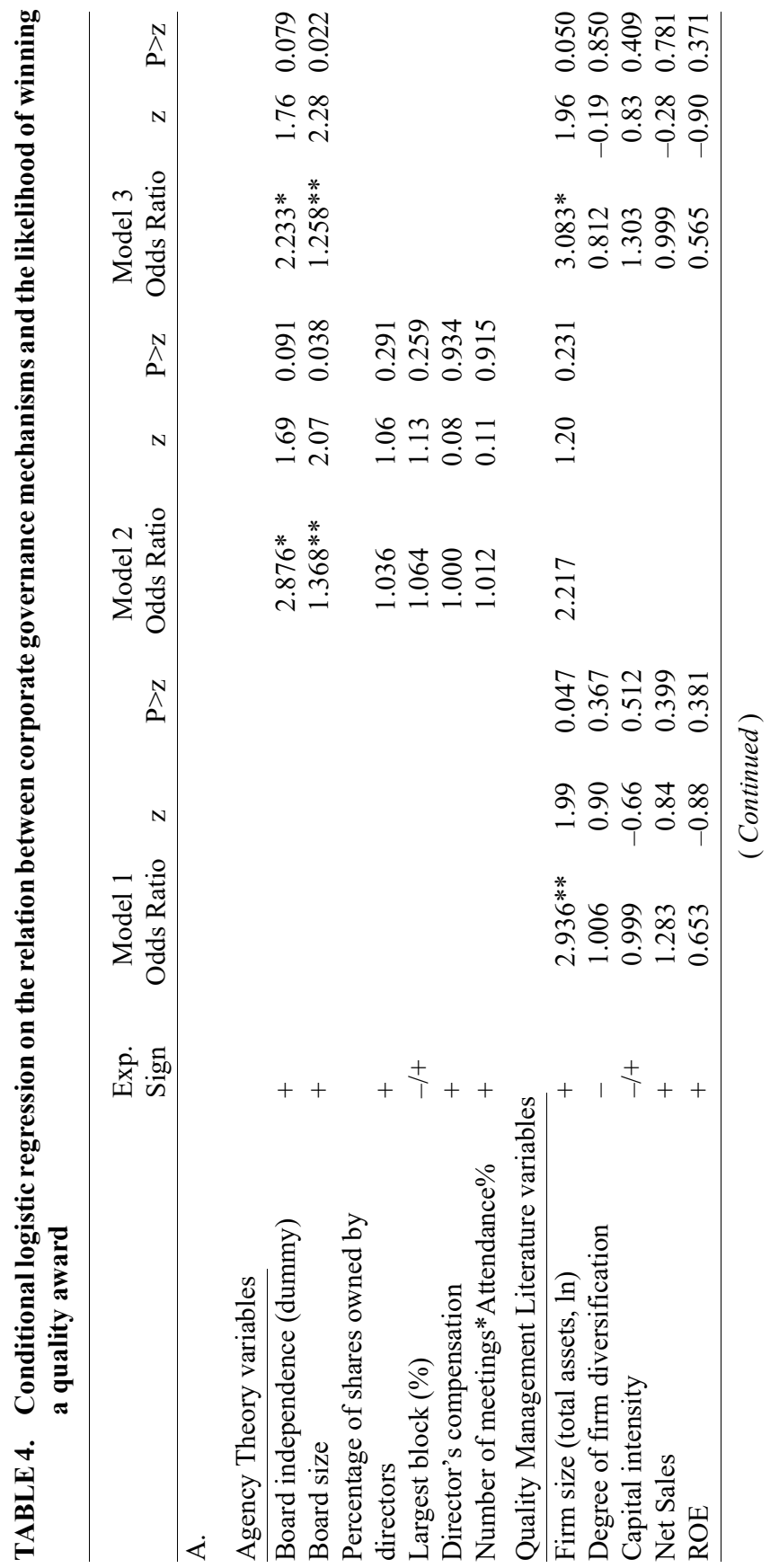




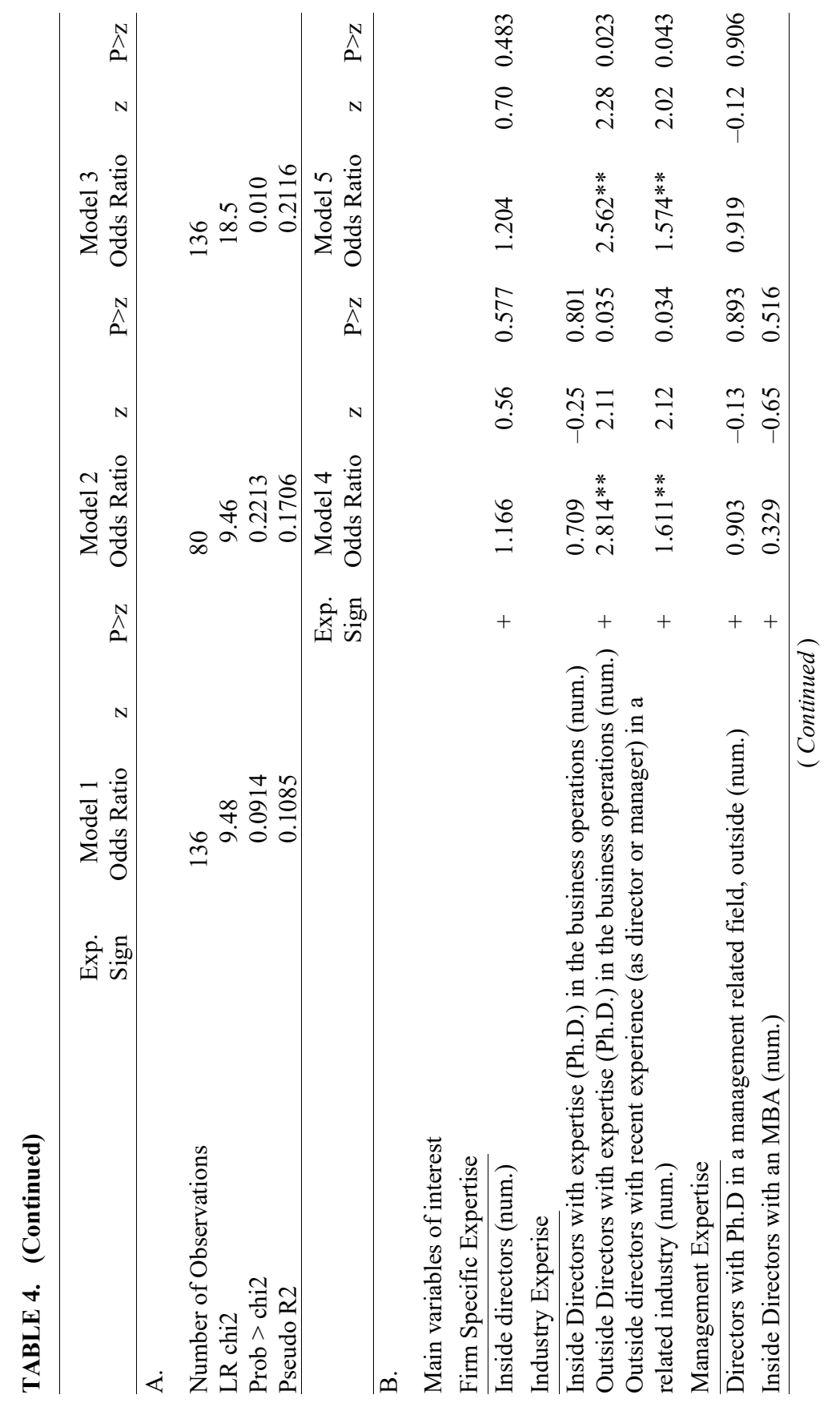




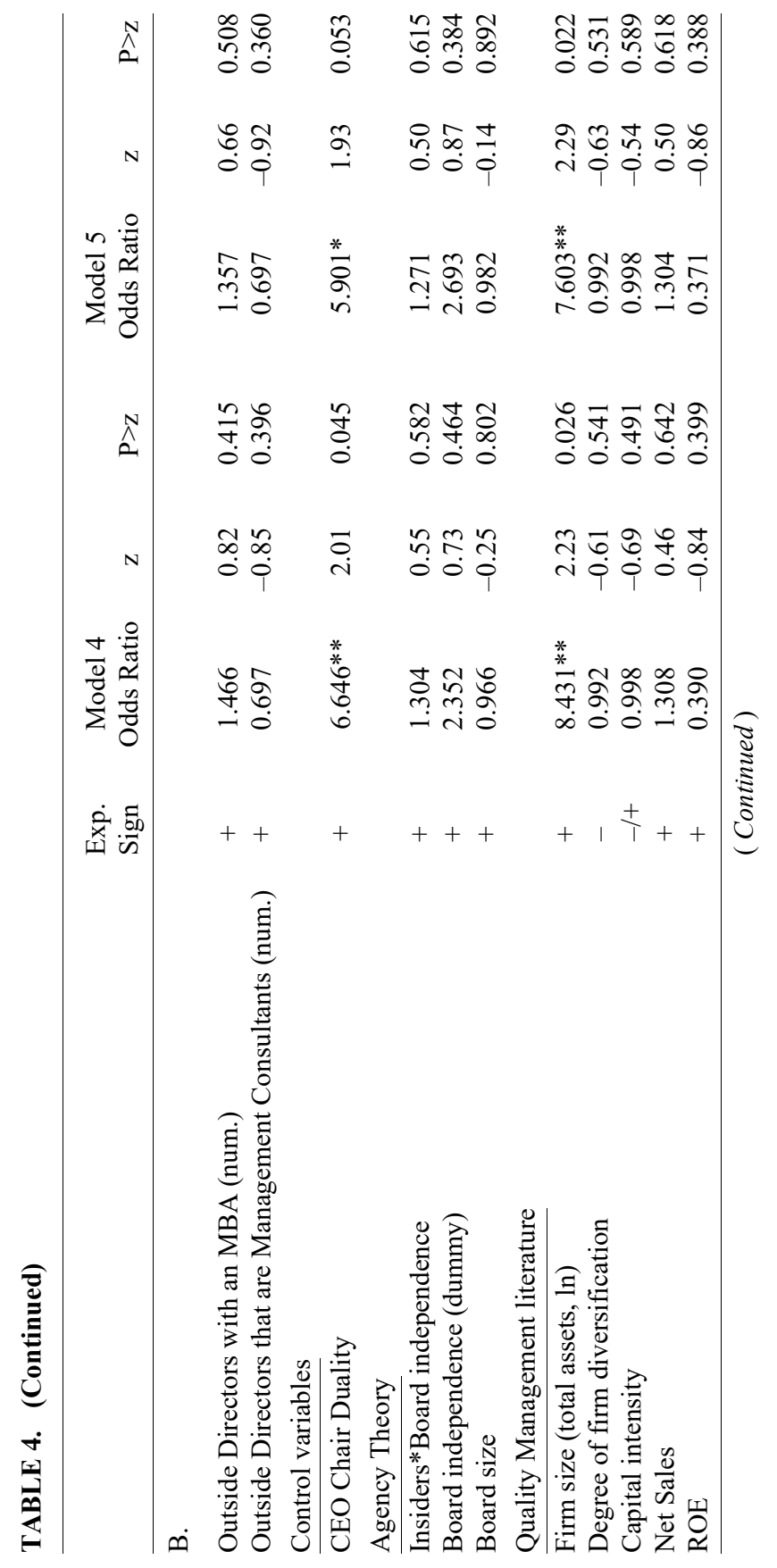




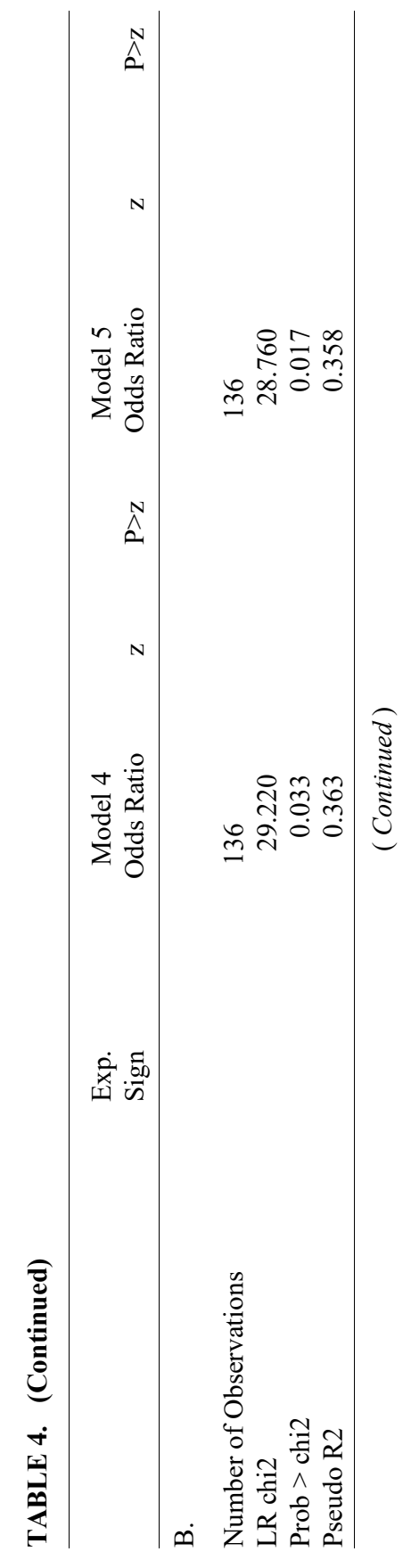




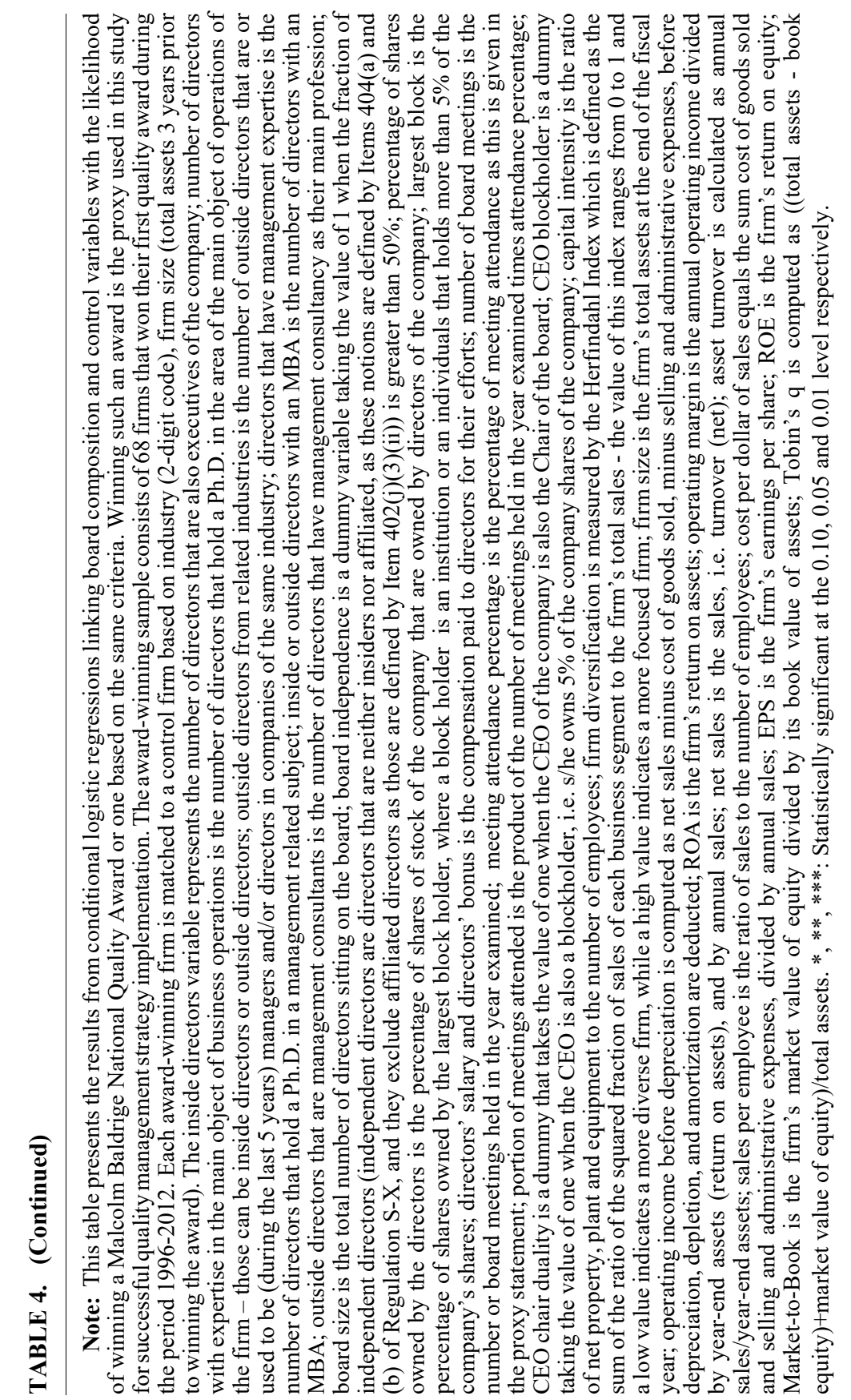


effects of board size (0.017) and firm size (0.085) are positive and statistically significant at the 0.05 and at the 0.01 levels, respectively (table 5, panel A).

In models four and five (tables 4, and 5, panel B) we add the main variables of interest, namely, the number of insiders, the number of directors that have a Ph.D. in the main object of business operations, the number of directors with recent experience in a related industry, the number of directors that have a Ph.D. in a management related field, the number of directors with an MBA, and the number of directors that are professional management consultants, along with a control variable indicating CEO power, namely CEO duality. Results of model 4, in table 4, panel B, show that two of the main variables of interest, namely the number of outside directors that have a Ph.D. in the main object of business operations and the number of outside directors with recent experience as director or manager in a related industry (odds ratios 2.814 and 1.611) - both variables that indicate industry expertise pertaining to hypothesis two $(\mathrm{H} 2)$ - are statistically significant (both at the 0.05 level of significance) and positively associated with the likelihood of winning a quality award. Marginal effects (table 5, panel B) for the two variables in model 4 are 0.050 and 0.023 , respectively, and statistically significant at the 0.05 level. Thus hypothesis two (H2) is not rejected. This result is further confirmed when in a reduced model (model 5) we run the model using only outside experts. In model 5 (table 4, panel B), the two variables representing the number of outside directors that have a Ph.D. in the main object of business operations and the number of outside directors with recent experience as director or manager in a related industry (odds ratios 2.562 and 1.574) are statistically significant (both at the 0.05 level of significance) and positively associated with the likelihood of winning a quality award. Marginal effects (table 5, panel B) for the two variables in model 5 are 0.047 and 0.022 , respectively, and statistically significant at the 0.05 level.

Contrary to expectations, the variable representing the number of inside directors is not statistically significant, thus hypothesis one (H1) that the number of these directors is positively related to the likelihood of winning a quality award is rejected. Hypothesis three (H3) regarding the number of management experts is also rejected, since none of the variables representing such directors (number of directors that have a $\mathrm{Ph} . \mathrm{D}$. in a management related field, directors with an MBA, and 


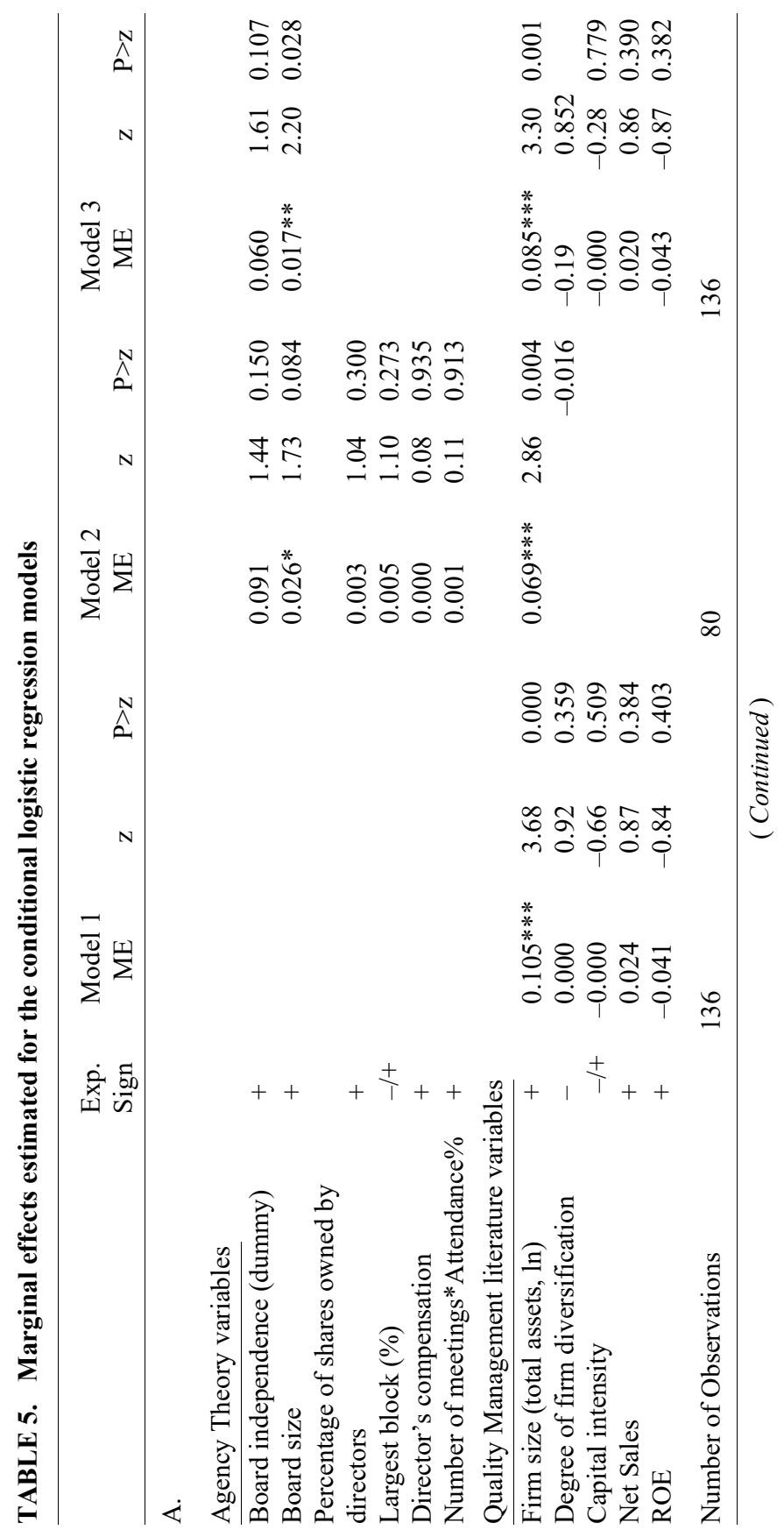




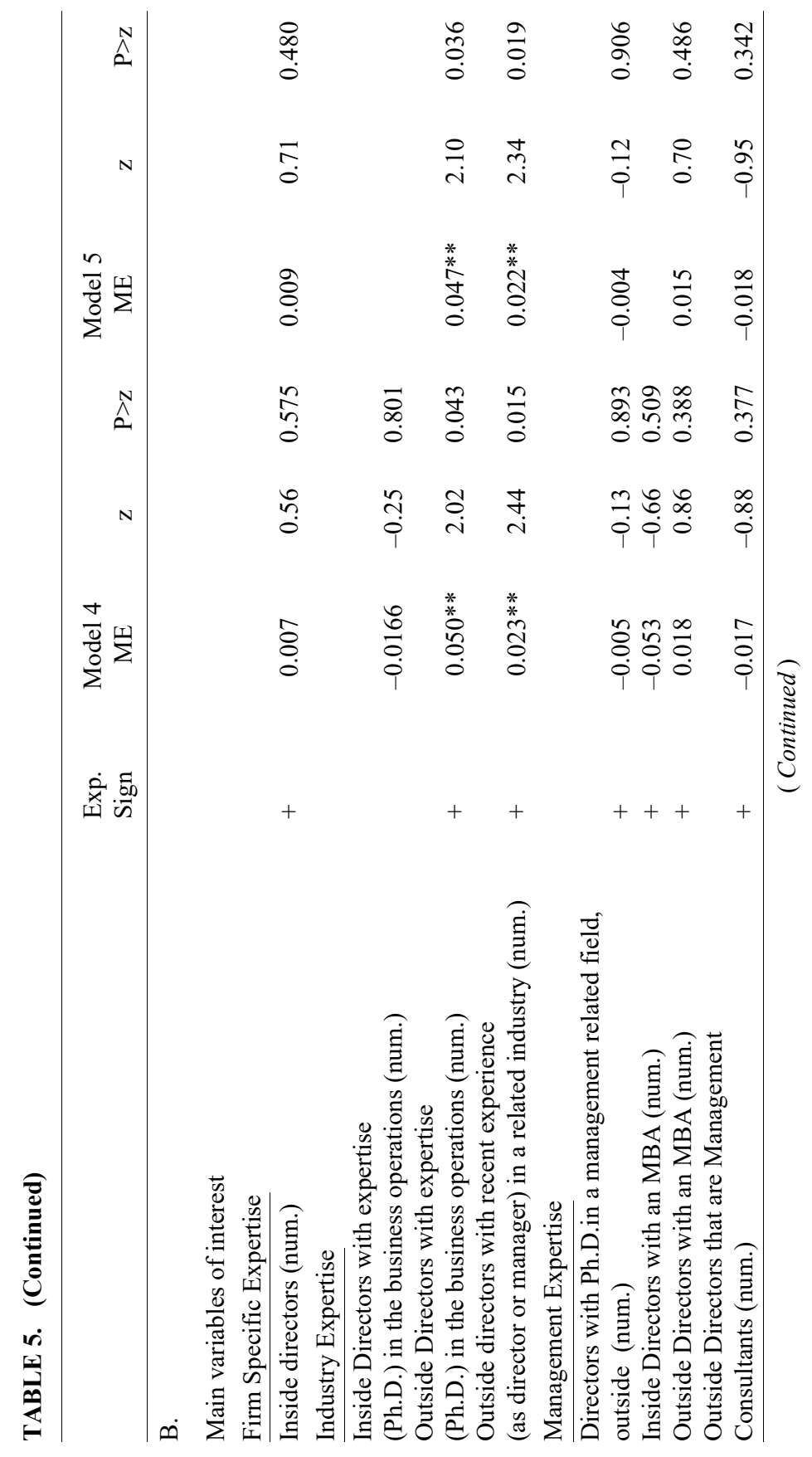




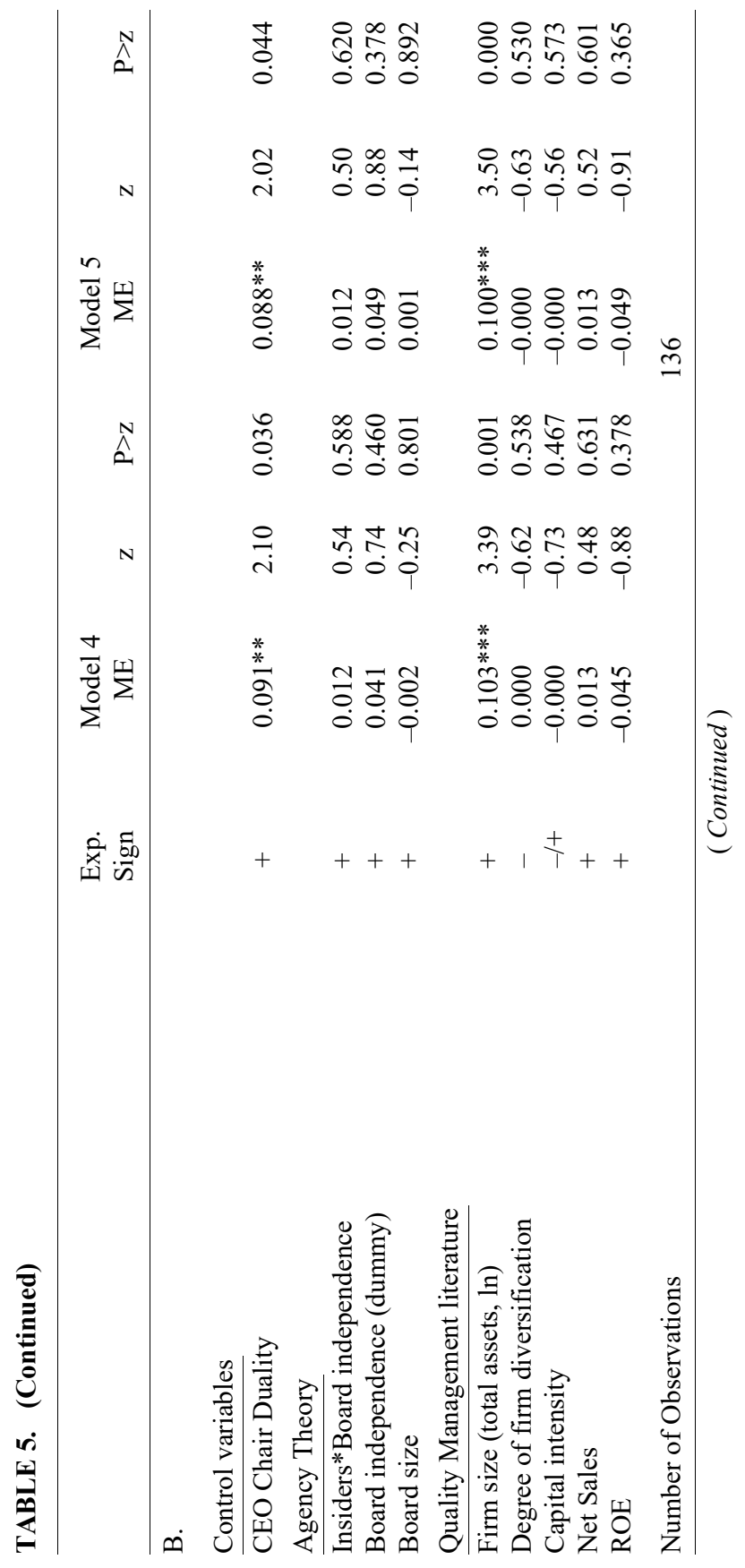




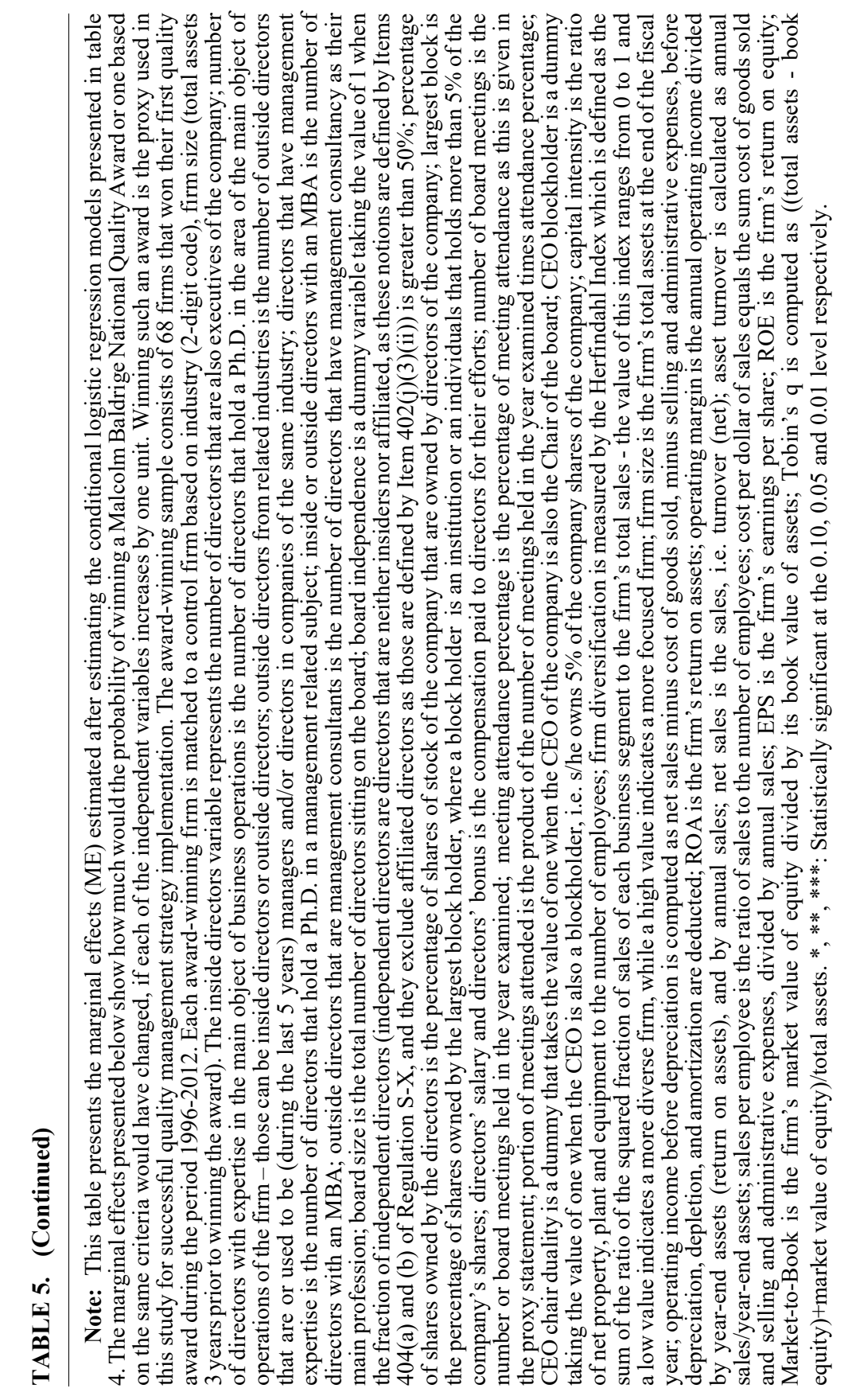


directors that are professional management consultants) are statistically significant.

Notably, the proxy for CEO power, namely CEO Chair Duality, is also statistically significant at the 0.05 and 0.10 levels, and with odds ratios of 6.646 and 5.901 for model 4 and 5, respectively (table 4, panel B). The marginal effects for the same variable (table 5, panel B) are 0.091 and 0.088 for models 4 and 5, respectively, and statistically significant at the 0.05 level for both models. Essentially similar results are obtained when we use an alternative variable for CEO power, namely CEO block-holder (not tabulated) ${ }^{19}$ Furthermore, the variable representing firm size is also statistically significant in both models four and five at the 0.05 level of significance; the odds ratios in table 4, panel B for firm size are 8.431 and 7.603, respectively for models 4 and 5. The marginal effects for the firm size are 0.103 and 0.100 for models 4 and 5, respectively, and significant at the 0.01 levels of significance for both models (table 5, panel B).

\section{Robustness tests pertaining to the relationship between $Q M$ and Board Composition}

In additional tests for robustness (not tabulated) we use proxies of management expertise such as directors' average age and directors' average tenure in place of and in addition to the proxies we describe in the previous section but they were not statistically significant in any model. Univariate comparisons did not discern any differences in means or in medians between the sample and the matching sample with respect to those proxies either.

Additionally, we ran models four and five using percentages instead of number of directors and the results remained essentially the same with respect to significance and signs (results not tabulated).

19. More variables were used as proxies for CEO power (results not tabulated) such as CEO tenure, CEO age, CEO busy-ness, whether the CEO was a Chief Operations Officer (COO) of this firm in the past, or the $\mathrm{COO}$ of another firm in the past (separately), whether the CEO is sitting on the nomination committee, and whether the CEO is an expert $\mathrm{him} /$ herself. Those variables were not statistically significant. The variable representing the number of outside directors with expertise (Ph.D.) in the business operations was statistically significant and positively related to the likelihood of winning a quality award in all cases. Moreover, we did explore the possibility to run models interacting CEO power with CEO expertise but in the sample of award winner firms there were only five expert dual CEOs, and only one expert CEO who was also a block-holder, while for the matching sample there was only one expert dual CEO and no expert CEOs block-holder. 
Furthermore, we examined whether it would matter whether the main business of the awarded unit was not related to the main object of business operations. That is, in the case that a department of the organization was awarded - instead of the whole organization, and that department was either a functional subunit of the organization (such as marketing or human resources) or a business subunit not in the same industry (2-digit sic code) as the company's (as it would be in the case of a financial services unit of a chain department store). We only counted five such cases; in fifty-seven cases the awarded unit was the whole organization, while in six cases the awarded unit was either a business unit with the same industry as the company, thus the expertise was still relevant (results not tabulated).

\section{E. The relationship between fit and firm performance}

The contingency hypothesis (H4) that organizational performance is contingent on the fit between QM and board composition, is assessed using residual analysis as described in section III, part D. Effectively, in this section, we examine the interplay of board composition, QM, and performance.

To test H4, we regressed the Pearson Residual of Model 4 from table 4 , i.e. the measure of "misfit" in separate linear regressions on each of the performance measurements described in section III, part D for each of the years from "year -3 " to "year +3 ", (from three years before winning a quality award up to three years after winning a quality award).$^{20}$ In addition, we regressed the measure of "misfit" on measures of abnormal returns around the award announcement date.

The results (table 6) show that Operating Income before Depreciation is positively related to the fit between board composition and strategy (since it is negatively related to the residual of the original conditional logistic regression), for all years except the year of the award and the year after that, at the 0.05 level of significance for years " -3 " and " +2 ", and at the 0.10 level of significance for years " -2 " and " -1 ". Operating Margin is negatively related to the residual of the original conditional logistic regression, meaning that the fit between board composition and strategy is positively related to the performance variable Operating Margin. Specifically, this is true for all years examined, at the 0.05 levels of significance for all years except "year 0 "

20. Essentially the same results were obtained when using Model 5. 


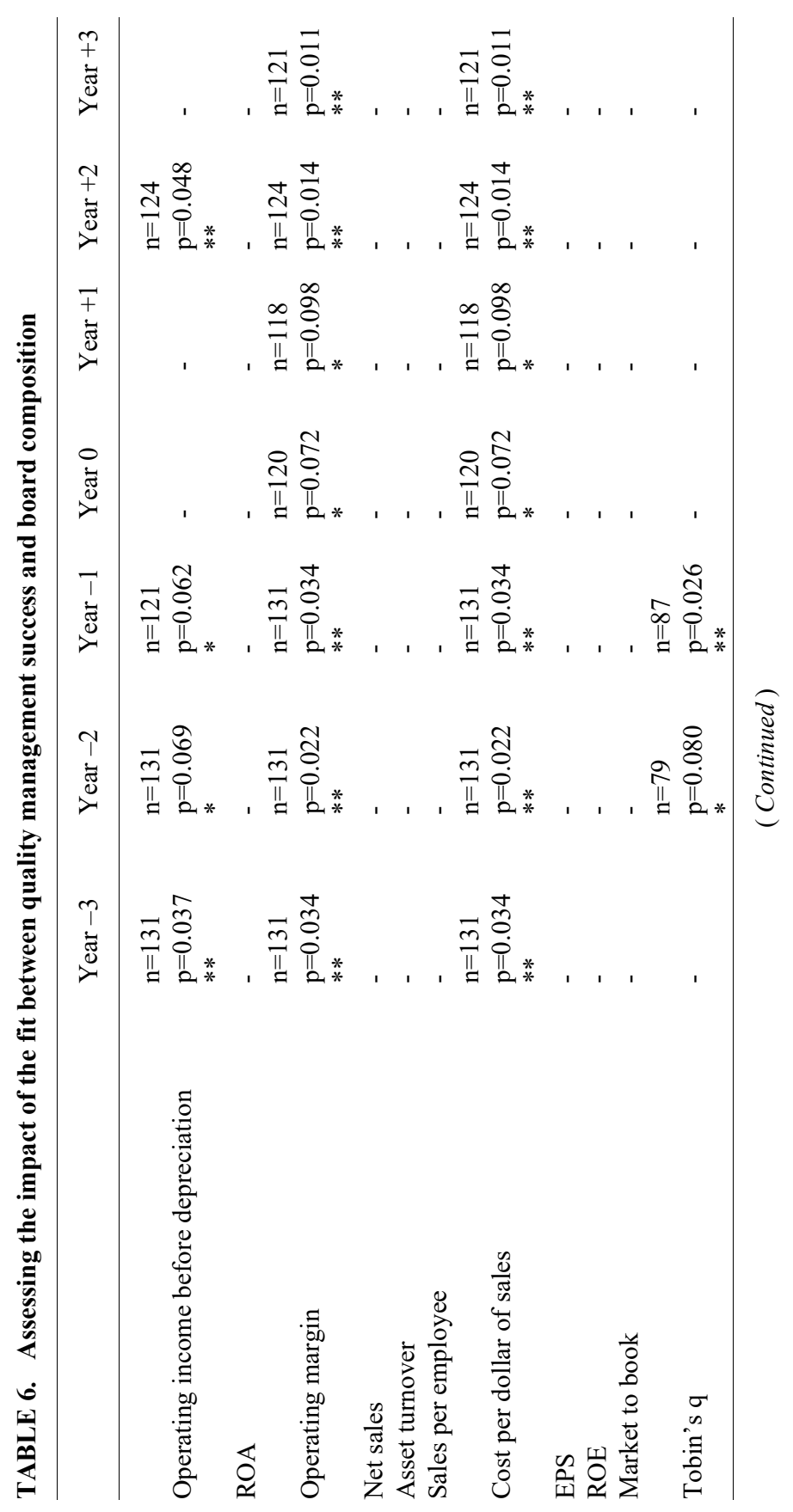




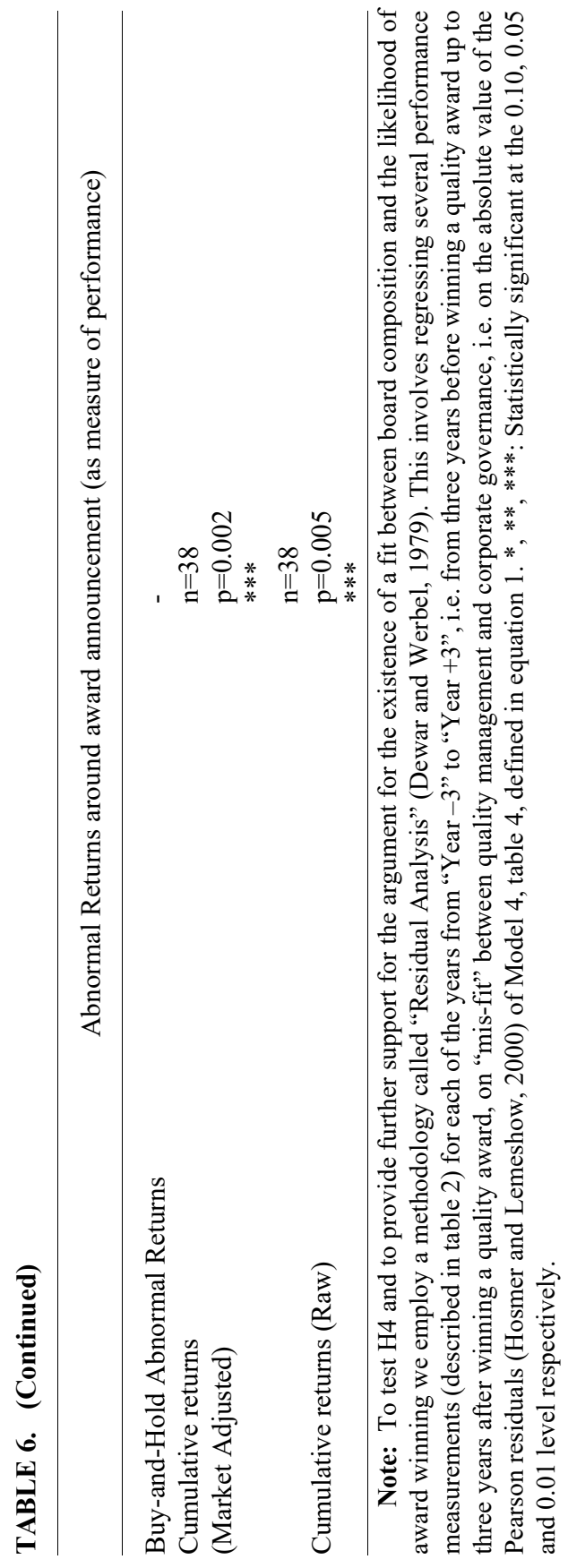


and "year +1 ", when it is 0.10 . Correspondingly, Cost per Dollar of Sales has the exact same relationship with fit, but as expected in the opposite direction. Further, the fit between board composition and strategy is positively related to the performance variable Tobin's Q, at years " -2 " (0.10 level) and " -1 " (0.05 level). "Year -1 " is according to Hendricks and Singhal (1996) the year when the implementation phase of the quality program is completed. ${ }^{21}$ Furthermore, Cumulative Market Adjusted Returns and for Cumulative Raw Returns (for the " \pm 10 days" window) are also positively related to the degree of fit at the 0.01 level of significance, even when controlling for the momentum factor, firm size, and book-to-market.

The above results demonstrate a contingent relationship of the fit between board composition and QM strategy with organizational performance variables, thus $\mathrm{H} 4$ is not rejected.

\section{F. Additional tests pertaining to performance}

Results from one-tailed t-tests (not tabulated) to investigate whether winning a quality award has a positive impact on the stock prices of winning firms revealed that for the Cumulative Market Adjusted Returns and for Cumulative Raw Returns for the \pm 10 days window, the mean was 0.026 and 0.053 respectively, and statistically significant at the 0.10 (p-value $=0.069)$ and 0.01 (p-value $=0.005)$ levels respectively. Pearson correlations of Cumulative Market Adjusted Returns and for Cumulative Raw Returns for the \pm 10 days window, with the variable representing whether a company won a quality award or not, were both positive and statistically significant at the 0.05 level. Separate regressions of Cumulative Market Adjusted Returns and the Cumulative Raw Returns for the \pm 10 days window on the award winning variable (while controlling for the momentum factor, firm size, and book-to-market ratio) showed that in both regressions, the coefficient of the variable representing whether a company won a quality award or not, were statistically significant both at the 0.01 levels of significance. These results remain essentially the same when we control for additional factors that Hendricks and Singhal (1997) proposed that might affect the relationship between QM and performance, i.e. degree of firm diversification and capital intensity.

21. It takes about twelve months from the end of the implementation phase to the award date, as the award evaluation process takes about that much (Hendricks and Singhal, 1996). 
Regressions with Abnormal Cumulative Returns and Buy-and-Hold abnormal returns as dependent variables and corporate governance and QM variables - and their interactions - as independent variables did not turn out any significant results.

\section{Conclusions and recommendations for future research}

The results of this study demonstrate that a relationship exists between board composition and quality management (QM) success, and they highlight the strategic-advisory role of the board of directors. Specifically, the findings suggest that the likelihood of a company obtaining a quality award is positively related to the number of outside directors that have expertise (a Ph.D.) in the main object of business operations of the company, the number of outside directors with recent experience (either as directors or managers) in related industries, the power of the CEO, and the size of the company. Furthermore, the fit between board composition and QM strategy is positively related with firm value.

Outside directors with Ph.D. in the company's main object of operations are what Markarian and Parbonetti (2007) call "support specialists" who contribute to capability building by providing companies with expertise, knowledge, and technical know-how, thus enhancing a company's competitive advantage. Competitive advantage is particularly important for a customer-oriented strategy such as a QM strategy (Mele and Colurcio, 2006). Moreover, these directors have a deep understanding of, and genuine interest in the business operations, which would lead to their greater involvement in strategy - as Rindova (1999) points out, the greater the strategic problem-solving expertise of directors, the more likely it is to participate in strategic decision-making. Furthermore, this result is in line with Faleye et al. (2013) who find that advisory directors are likely to possess doctorate degrees.

Outside directors with recent experience in related industries are able to provide industry insights from the industry the company operates in, or from upstream/downstream industries, including a deep understanding of the risk and opportunity profiles of the related industries (Dass et al., 2014, Faleye et al., 2014). They have knowledge of customer and supplier needs, which is important in a customer-oriented QM context. Thus, they are in a position to contribute 
superior inputs in strategic decision-making (Faleye et al., 2014). Moreover, these directors may even facilitate access to upstream/downstream industries and to key industry connections, and assist in acquiring resources (Dass et al., 2014; Faleye et al., 2014).

The variables representing the above types of expert directors remain statistically significant, even when controlling for CEO power. Moreover, CEO power is positively related to the likelihood of winning a quality award. This may seem contrary to the results of others, such as Golden and Zajac (2001) who find that with higher CEO power comes lower influence on corporate strategy from other directors, and to the results of Faleye et al. (2013) who find that the value effect of advisory directors is weaker when CEO power is higher. Yet, based on the credibility theory, the expertise of the directors can increase the likelihood that the CEO will seek these directors' input and follow their advice (Faleye et al., 2014). It would be interesting if future research investigated the interaction between expertise and CEO power and its relationship to firm value. We did explore the possibility to run models interacting CEO power with CEO expertise in this study, but as it is explained in the paper, the sample did not permit further analysis of this issue.

The results are consistent with research that shows that complex firms are likely to include more outside experts on their boards as these directors enhance the firm's ability to handle complexity (Markarian and Parbonetti, 2007; Coles et al., 2008; 2012). Furthermore, Faleye et al. (2013) show that in the case of complex firms with increased advising requirements, the effect of advisory directors on value is more pronounced. Even without implying causality, it seems that expert opinions on the board of directors matter in a QM strategy and they are invited on the board. Another explanation - and perhaps a limitation of this study - could be that the presence of these directors may affect the probability of applying for such awards. This alternative explanation is also interesting by its own, and does not diminish the value of the results; the fact remains that even without claiming causation, these characteristics discern award winning firms from their non-winner counterparts.

Inside directors do not seem to be associated with the likelihood of QM success. In fact, it seems that QM firms do not even include inside directors at a higher rate than non-QM firms do. This result could be an empirical confirmation of what Soltani et al. (2008) discuss: Despite the fact that in the QM literature, top management involvement and 
commitment in QM strategy is highly encouraged, in practice, this aspect is greatly overlooked - at least we cannot say that it is encouraged in the way hypothesized in this study, i.e. by including more inside directors on the board. Because of that, we cannot infer whether or not the involvement of insiders in the board of directors of a company is related to the success of quality initiatives. On the other hand, the lack of relationship could be because any beneficial impact of inside directors on QM may cancel out due to them having a conflict of interest, in accordance to some studies from the agency perspective (see for example Weisbach, 1988; Byrd and Hickman, 1992; and Cotter et al., 1997), as these directors might have become entrenched, thus not always striving to implement what is optimal.

Directors with management expertise -i.e. either with a Ph.D. in management related fields, or an MBA, or directors that are professional management consultants - do not appear to be related to the likelihood of QM success. In fact, both award winners and non-winners, appear to employ directors with similar management expertise. The reason could be that QM firms may rely on expert systems specifically designed for QM (Franz and Foster, 1992).

Further, the residual analysis results show that there is a positive relationship between fit and at least some measures of firm performance, namely, operating income before depreciation, operating margin, Tobin's Q, Cumulative Market Adjusted Returns, and Cumulative Raw Returns (for the " \pm 10 days" window), while there is a negative relationship with cost per dollar of sales. These results demonstrate that even with this conservative test of fit, it appears to exist - at least - a linear fit between board composition and winning a quality award (see Dewar and Werbel, 1979).

Going back to the research questions, we conclude that an appropriate board structure that fits the QM strategy appears to exist, and this fit is positively related with firm value. ${ }^{22}$ This study has

22. According to Dewar and Werbel (1979), the conservativeness of the residual analysis, as well as its linearity could be the reason for non-detection of significance for the rest of the performance measures employed when using the approach on the rest of the performance measures. An alternative, interesting explanation for the lack of significance comes from a selection/evolutionary perspective (Drazin and Van De Ven, 1984; Hannan and Freeman, 1990; Carroll and Hannan, 2001). Under this perspective, the sample QM firms have successfully evolved to a point at which their ability to survive a QM strategy is due to an equilibrium between board composition and the strategy they undertake. That is, the firms that embarked on a quality management strategy had shaped their boards through time evolving in such a way as to accommodate and survive the strategy. Though this adaptation 
revealed board structure characteristics that differentiate quality award winning firms from their matching counterparts. Furthermore, the results link board composition to QM success and firm value. Moreover, the findings confirm the notion that board composition is contextual, and pave the path for further investigating issues pertaining to the relationship of the board of directors - and corporate governance in general - with business excellence.

Accepted by: P.C. Andreou, PhD, Editor-in-Chief(Pro-Tem), July 2016

\section{References}

Adams, R. B., and Ferreira, D. 2007. A theory of friendly boards. The Journal of Finance 62(1), 217-250.

Agrawal A., and S. Chadha, S. 2005. Corporate governance and accounting scandals. Journal of Law and Economics 48, 371-406.

Agrawal, A., and C. Knoeber 1996. Firm performance and mechanisms to control agency problems between managers and shareholders. Journal of Financial and Quantitative Analysis 31, 377-397.

Balasubramanian, S. K.; Mathur, I.; and Thakur, R. 2005. The impact of high-quality firm achievements on shareholder value: Focus on Malcolm Baldrige and JD Power and Associates awards. Journal of the Academy of Marketing Science 33(4), 413-422.

Barney, J. 1991. Firm resources and sustained competitive advantage. Journal of Management 17, 99-120.

Baysinger, B.D., and Hoskisson, R.E. 1990. The composition of the board of directors and strategic control: Effects of corporate strategy. Academy of Management Review 15, 72-87.

Bhagat S., and Black, B. 2002. The Non-Correlation between Board Independence and Long-Term Firm Performance. Journal of Corporation Law 27, 231-274.

Boone, A.L.; Field, L.C.; Karpoff, J.M.; and Raheja, C.G. 2007. The determinants of corporate board size and composition: An empirical analysis. Journal of Financial Economics 85(1), 66-101.

Boubaker, S. 2007. Ownership-control discrepancy and firm value: Evidence from France. Multinational Finance Journal 11(3/4), 211-252.

was necessary for achieving quality excellence, the changes are not expected - under this perspective - to further relate to any other measures of performance. It would be interesting if further studies investigate the evolution of the boards of firms that pursue excellence perhaps using time-series methodologies. 
Boumosleh, A. S., and Reeb, D. M. 2009. Inside directors, managerial competition, and the asymmetric information problem. SSRN Working Paper Series.

Brickley, J., and Zimmerman, J. 2010. Corporate governance myths: Comments on Armstrong, Guay and Weber. Journal of Accounting and Economics 50, 235-245.

Boyd, B. K. 1995. CEO duality and firm performance: A contingency model. Strategic Management Journal 16 (4), 301-312.

Byrd, J., and Hickman, K. 1992. Do outside directors monitor managers? Evidence from tender offer bids. Journal of Financial Economics 32, 195-221.

Carroll, G.R., and Hannan, T. 2001. The Demography of Corporations and Industries. New York: Oxford University Press.

Charitou, A.; Lambertides, N.; and Trigeorgis, L. 2007. Earnings behaviour of financially distressed firms: The role of institutional ownership. Abacus 43(3), 271-296.

Chatterjee, S. 2009. Does increased equity ownership lead to more strategically involved boards? Journal of Business Ethics 87 (1), 267-277.

Coles, J.; Daniel, N.; Naveen, L. 2008. Boards: Does one size fit all? Journal of Financial Economics 87(2), 329-356.

Coles, J. L.; Daniel, N. D.; and Naveen, L. 2012. Board advising. Available at SSRN 2002250.

Coles, J. L.; Daniel, N. D.; and Naveen, L. 2014. Co-opted boards. Review of Financial Studies 27(6), 1751-1796.

Corbett, C. J.; Montes-Sancho, M. J.; and Kirsch, D. A. 2005. The financial impact of ISO 9000 certification in the US: An empirical analysis. Management Science 51(7), 1046-1059.

Cotter, J.; Shivdasani, A.; and Zenner, M. 1997. Do independent directors enhance target shareholder wealth during tender offers? Journal of Financial Economics 43, 195-218.

Daily, C.M.; Dalton, D.; and Cannella, A. 2003. Corporate governance: Decades of dialogue and data. Academy of Management Review 28, 371-821.

Dalton, D. R.; Daily, C. M.; Certo, S. T.; and Roengpitya, R. 2003. Meta-analyses of financial performance and equity: Fusion or confusion? Academy of Management Journal 46, 13-26.

Dass, N.; Kini, O.; Nanda, V.; Onal, B.; and Wang, J. 2013. Board Expertise: Do Directors from Related Industries Help Bridge the Information Gap? Review of Financial Studies 27(5), 1533-1592.

Defond, M.; Hann, R.; and Hu, X. 2005. Does the market value financial expertise on audit committees of boards of directors? Journal of Accounting Research 43, 153-193.

Donaldson, L. 2001. The contingency theory of organizations. CA: Sage Publications, Thousand Oaks. 
Drazin, R., and A. H. Van de Ven 1985. Alternative forms of fit in contingency theory. Administrative Science Quarterly 30, 514-539.

Drobetz, W.; Von Meyerinck, F.; Oesch, D.; and Schmid, M. M. 2014. Board Industry Experience, Firm Value, and Investment Behavior. University of St. Gallen, School of Finance Research Paper, (2014/01).

Easton, G. S., and Jarrell, S. L. 1998. The effects of total quality management on corporate performance: An empirical investigation. Journal of Business 71(2), 253-307.

Ensign, P.C. 2001. Concept of fit in organizational research. International Journal of Organization Theory and Behavior 4 (3-4), 287-306.

Faleye, O. 2007. Classified boards, firm value, and managerial entrenchment. Journal of Financial Economics 83(2), 501-529.

Faleye, O.; Hoitash, R.; and Hoitash, U. 2014. Industry expertise on corporate boards. Northeastern U. D'Amore-McKim School of Business Research Paper, (2013-04).

Faleye, O.; Hoitash, R.; and Hoitash, U. 2013. Advisory directors. Available at SSRN 1866166.

Fama, E. F., and M. C. Jensen 1983. Separation of ownership and control. Journal of Law and Economics 26, 301-325.

Franz, L. S., and Foster, S. T. Jr. 1992. Utilizing a knowledge-based decision-support system as total quality management consultant. International Journal of Production Research 30 (9), 2159-2171.

Gerdin, J. 2005. The impact of departmental interdependencies and management accounting system use on subunit performance: A second look. The European Accounting Review 14, 335-340.

Gerdin, J., and Greve, J. 2008. The appropriateness of statistical methods for testing contingency hypotheses in management accounting research. Accounting, Organizations and Society,33(7), 995-1009.

Güner, A. B.; Malmendier, U.; and Tate, G. 2008. Financial expertise of directors. Journal of Financial Economics 88(2), 323-354.

Hannan, M.T., and Freeman, J. 1990. Organizational Ecology. Cambridge, MA: Harvard University Press.

Hendricks, K. B., and Singhal V. R. 2001a. The long-run stock price performance of firms with effective TQM programs. Management Science 47(3), 359-68.

Hendricks, K. B., and Singhal V. R. 2001b. Firm characteristics, total quality management, and financial performance. Journal of Operations Management 19, 269-285.

Hendricks, K. B., and Singhal, V. R. 1996. Quality awards and the market value of the firm: An empirical investigation. Management Science 42(3), 415-436.

Hendricks, K. B., and Singhal, V. R. 1997. Does implementing an effective TQM program actually improve operating performance? Empirical evidence from firms that have won quality awards. Management Science 43(9), 1258-1274. 
Hillman, A. J.; Cannella, A. A.; and Paetzold, R. L. 2000. The resource dependence role of corporate directors: Strategic adaptation of board composition in response to environmental change. Journal of Management Studies 37, 235-254.

Hosmer, D. W., and Lemeshow S. 2000. Applied Logistic Regression. New York, NY, John Wiley \& Sons.

Jacob, R. A.; Madu, C. N.; and Tang, C. 2012. Financial performance of Baldrige Award winners: A review and synthesis. International Journal of Quality \& Reliability Management 29(2), 233-240.

Jensen, M. C., and Meckling, W. H. 1976. Theory of the firm: Managerial behavior, agency costs and ownership structure. Journal of Financial Economics 3, 305-360.

Johnson, J. L.; Daily, C. M; and Ellstrand, A. E. 1996. Research on boards of directors: A review and research agenda. Journal of Management 22, 409-438.

Lehn, K. M.; Patro, S.; and Zhao, M. 2009. Determinants of the Size and Composition of US Corporate Boards: 1935 2000. Financial Management 38(4), 747-780.

Linck, J.; Netter, J.; and Yang, T. 2008. A large sample study on board changes and determinants of board structure. Journal of Financial Economics 87(2), 308-328.

Makadok, R. 2001. Toward a synthesis of the resource-based and dynamic-capability of rent creation. Strategic Management Journal 22, 387401.

Markarian, G., and Parbonetti, A. 2007. Firm complexity and board of director composition. Corporate Governance: An International Review 15 (6), 1224-1243.

Masulis, R. W.; Wang, C.; and Xie, F. 2012. Globalizing the boardroom-The effects of foreign directors on corporate governance and firm performance. Journal of Accounting and Economics 53(3), 527-554.

Mele, C., and Colurcio, M. 2006. The evolving path of TQM: Towards business excellence and stakeholder value. International Journal of Quality \& Reliability Management 23(5), 464-89.

Naveen, L.; Daniel, N. D.; and McConnell, J. J. 2013. The advisory role of foreign directors in US firms. Available at SSRN 2023420.

Minton, B. A.; Taillard, J. P.; and Williamson, R. 2014. Financial expertise of the board, risk taking, and performance: Evidence from bank holding companies. Journal of Financial and Quantitative Analysis 49(02), 351-380.

Muth M., and Donaldson L. 1998. Stewardship theory and board structure: A contingency approach. Corporate Governance: An International Review 6 (1), 5-28.

Nicolau, J. L., and Sellers, R. 2002. The stock market's reaction to quality certification: Empirical evidence from Spain. European Journal of Operational Research 142, 632-641. 
Peterson, C. A.; Philpot, J.; and O'Shaughnessy, K. C. 2007. African American Diversity in the Boardrooms of the US Fortune 500: Director presence, expertise and committee membership. Corporate Governance: An International Review 15(4), 558-575.

Przasnyski, Z. H., and Tai, L. S. 2002. Stock performance of Malcolm Baldrige National Quality Award winning companies. Total Quality Management 13(4), 475-488.

Pugliese, A.; Bezemer, P. J.; Zattoni, A.; Huse, M.; Van den Bosch, F. A.; and Volberda, H. W. 2009. Boards of directors' contribution to strategy: A literature review and research agenda. Corporate Governance: An International Review 17(3), 292-306.

Rindova, V.P. 1999. What corporate boards have to do with strategy: A cognitive perspective. Journal of Management Studies, 36, 953-975.

Sandholm, L. 2005. Strategic plan for sustainable excellence. Total Quality Management \& Business Excellence 16 (8), 1061-1068.

Scott, W. R. 1998. Organizations: Rational, Natural, and Open Systems. NJ, Prentice Hall, Upper Saddle River.

Soltani, E.; Lai, P.; Javadeen, S.R.S.; and Gholipour, T.H. 2008. A review of the theory and practice of managing TQM: An integrative framework. Total Quality Management \& Business Excellence 19(5), 461-479.

Stiles, P., and Taylor, B. 1996. The strategic role of the board. Corporate Governance: An International Review 4, 3-10.

Sullivan, J. J. 1990. Experts, expert systems, and organizations. Organization, Management and Expert Systems. New York: Walter de Gruyter.

Venkatraman, N. 1989. The concept of fit in strategy research: Toward verbal and statistical correspondence. Academy of Management Review 14 (3), 423-444.

Wang, C., Xie, F., and Zhu, M. 2015. Industry expertise of independent directors and board monitoring. Journal of Financial and Quantitative Analysis 50(05), 929-962.

Weisbach, M. S. 1988. Outside directors and CEO turnover. Journal of Financial Economics, Elsevier, 20(1-2) 431-460.

Wruck, K.H., and Jensen, M.C. 1994. Science, specific knowledge, and total quality management. Journal of Accounting and Economics 18(3), 247-287.

Yin, X., and Zajac E. 2004. The strategy/governance structure fit relationship: Theory and evidence in franchising arrangements. Strategic Management Journal 25(4), 365-383.

Yoo, B.; Donthu, N.; and Lee, S. 2000. An examination of selected marketing mix elements and brand equity. Journal of the Academy of Marketing Science 28 (2), 195-211.

York, K. M., and Miree, C. E. 2004. Causation or covariation: An empirical re-examination of the link between TQM and financial performance. Journal of Operations Management 22, 291-311. 